\title{
IMPACT OF REPEATED BOUTS OF ECCENTRIC EXERCISE ON SKELETAL MUSCLE MORPHOLOGY AND MYOGENIC GENE EXPRESSION
}

$\mathrm{PhD}$ Thesis

\section{Andreas Costa}

Semmelweis University

Doctor School for Sports Science
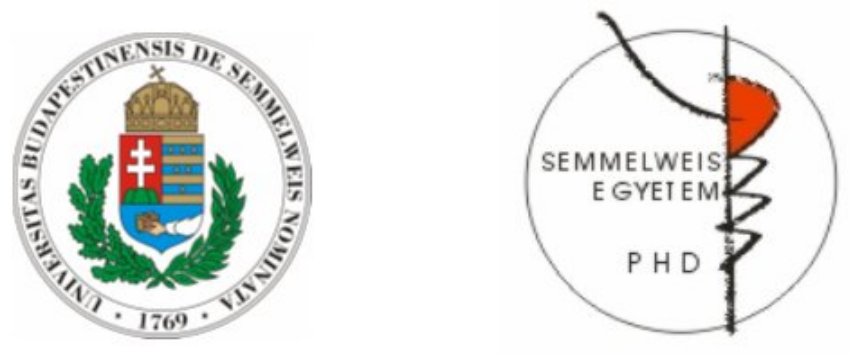

Supervisor: Prof. Dr. József Tihanyi, DSc

Opponents: Prof. Dr. Lajos Ángyán, DSc Prof. Dr. Ákos Koller, DSc

Chairman of the Committee: Prof. Dr. Zsolt Radák, DSc Members of the Committee: Prof. Dr. József Pucsok, DSc Dr. Rita Kiss, CSc

Prof. Dr. János Mészáros, CSc

\section{Budapest}




\begin{abstract}
Impact of repeated bouts of eccentric exercise on skeletal muscle morphology and myogenic gene expression
\end{abstract}

The purpose of this study is to determine the effects of repeated-bouts of eccentric exercise for six consecutive days on the transcriptional alteration of myogenic (MyoD, Myogenin, Myf5, and Myostatin) and cell cycle (P21, Ki-67) regulatory genes as well as on the indirect (CK and LDH activity, MAT, and DOMS) and direct (myofiber and sarcolemma damage) markers of skeletal muscle damage in a group of middle-aged untrained individuals. This was done in an attempt to determine the appropriateness of exercise continuation with damaged muscles. Fifteen healthy untrained males were recruited for this study. The exercise group $(n=9)$ successfully completed six sets of 15 reps of maximum voluntary eccentric contractions, for six consecutive days, using a dynamometer (Multicont-II). The control group $(n=6)$ remained in a sedentary state. Blood and biopsy samples were obtained from all subjects one week prior to exercise, immediately after bout 3 (day 3), and $24 \mathrm{~h}$ after the last training session at day 7. Blood samples were analyzed for creatine kinase (CK) and lactate-dehydrogenase (LDH) activity. All biopsies were stained with standard haematoxylin-eosin staining and immunohistochemically using antibodies specific for fibronectin and desmin antigens. The results of our study indicated no evidence of gross myofiber damage. In addition no sarcolemma damage and no loss of desmin were observed as stained by anti-fibronectin and anti-desmin antibody respectively. Despite the lack of sarcolemma and myofiber damage, $\mathrm{CK}$ and LDH activities were significantly increased at all times measured. The results of mRNA gene expression showed that Myostatin mRNA expression dramatically decreased but the expression patterns of MRFs was impaired such that, with the exception of myogenin that showed a moderate non sustained increase, MyoD and MYf5 response was minimal. Although we observed no gross myofiber and sarcolemma damage in 8 of 9 subjects we cannot ascertain the appropriateness of exercise continuation with affected muscles prior full recovery. This is due to the impaired expression patterns of MRFs. Under these conditions exercise continuation may be associated with impaired muscle growth and/or regeneration. 


\section{Bibliographical data of most important publications:}

Costa A., Dalloul H., Hegyesi H., Apor P., Csende Z., Racz L., Vaczi M., Tihanyi J. 2007. Impact of repeated bout of eccentric exercise on myogenic gene expression. Eur $J$ Appl Physiol. 101(4):427-436

Costa A., Orosz Z., Apor P., Csaba N., Siamilis S., Csende Z., Racz L., Tihanyi J. 2008. Impact of Repeated Bouts of Eccentric Exercise on Sarcolemma Disruption in Human Skeletal Muscle. Acta Physiol Hung. [Epub ahead of print] 


\section{TABLE OF CONTENTS}

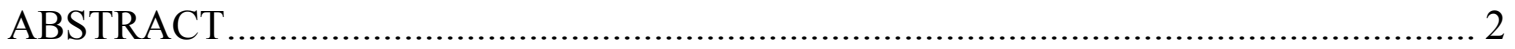

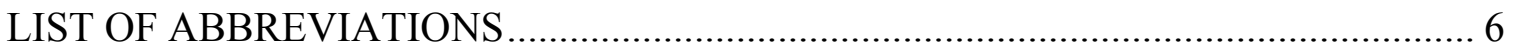

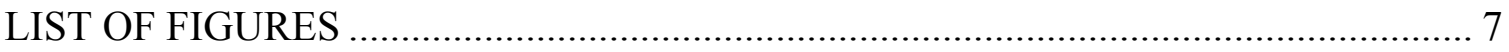

CHAPTER I, INTRODUCTION ................................................................................ 8

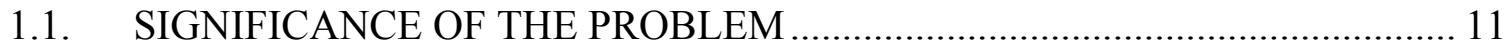

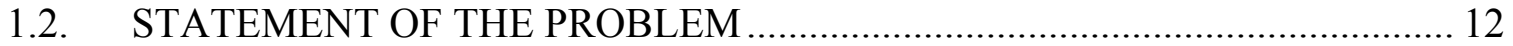

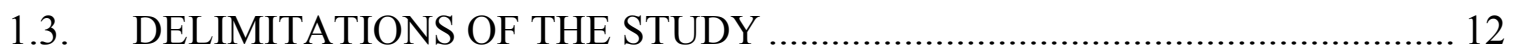

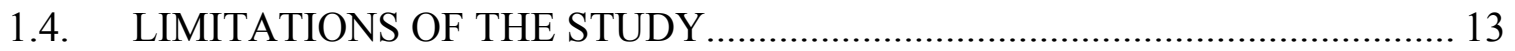

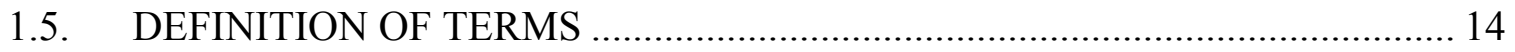

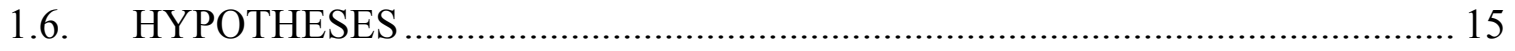

CHAPTER II, REVIEW OF RELATED LITERATURE ................................... 16

2.1. DIRECT INDICES OF SKELETAL MUSCLE DAMAGE ............................... 16

2.2. INDIRECT INDICES OF SKELETAL MUSCLE DAMAGE .......................... 20

2.2.1. Indirect Evidence for Eccentric Contraction-Induced Muscle Damage....... 21

2.2.2. Indirect Evidence against Eccentric Contraction-Induced Muscle Damage 25

2.3. MUSCLE REGENERATION, MYOSTATIN AND MRFS.............................. 26

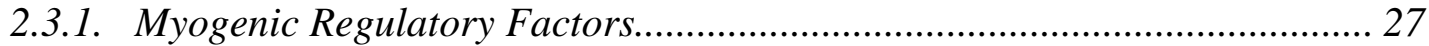

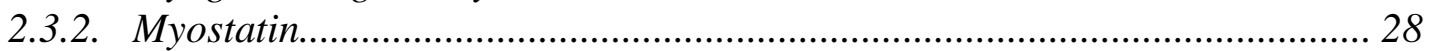

2.4. RESISTANCE EXERCISE, MRFS AND MYOSTATIN ................................ 31

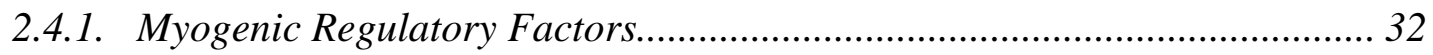

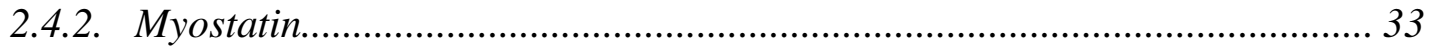

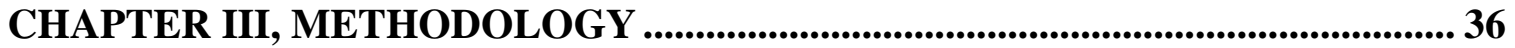

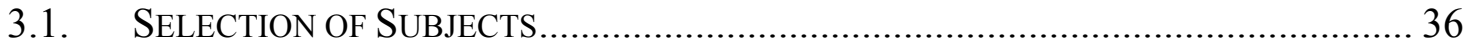

3.2. INSTRUMENTS AND COLLECTION OF DATA .................................................. 36

3.2.1. Instruments and procedures for collecting biomechanical data and DOMS 36

3.2.2. Instruments and procedures for collecting muscle biopsies and the

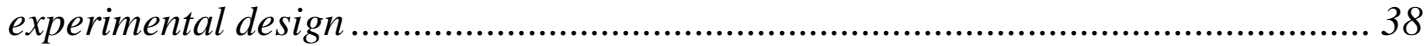

3.2.3. Instruments and procedures for collecting mRNA expression data............... 39

3.2.4. Instruments and procedures for collecting Creatine kinase (CK), lactate

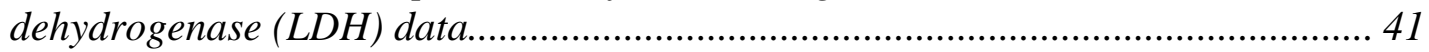

3.2.5. Instruments and procedures for morphological data collection................... 41

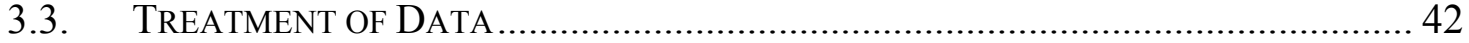




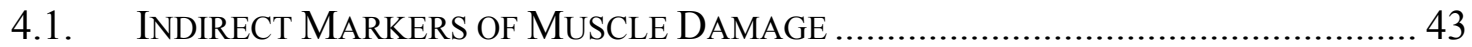

4.2. DiRECT MARKERS OF MuSCle DAMAGE …….................................................. 46

4.3. MYOGENIC REGULATORY FACTORS (MRFS) .................................................. 50

4.4. MARKERS OF PROLIFERATION AND DIFFERENTIATION..................................... 52

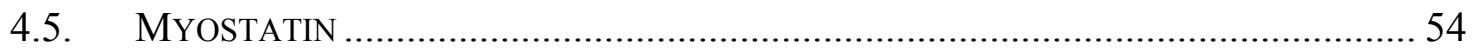

CHAPTER V, INTERPRETATION OF THE RESULTS ........................................... 55

5.1. MUSClE DAMAGE, DiRECT AND INDIRECT MARKERS...................................... 55

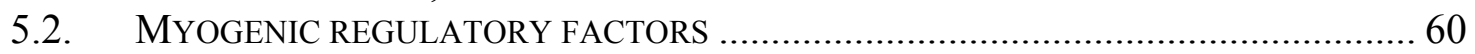

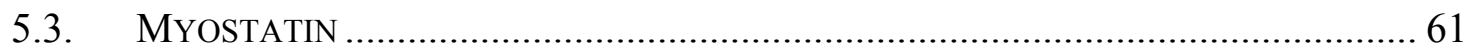

5.4. CELL PROLIFERATION AND DifFERENTIATION ................................................... 62

CHAPTER VI, SUMMARY .......................................................................................... 64

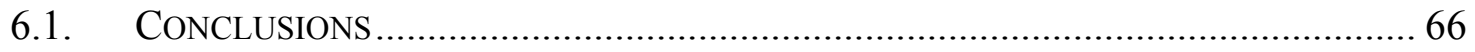

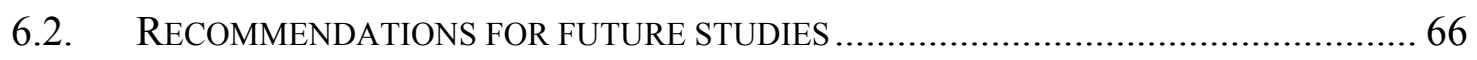

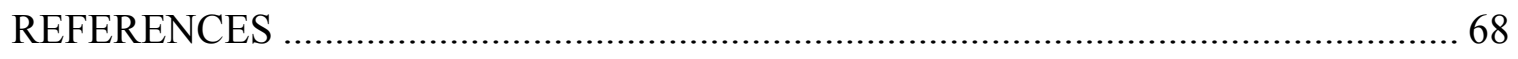

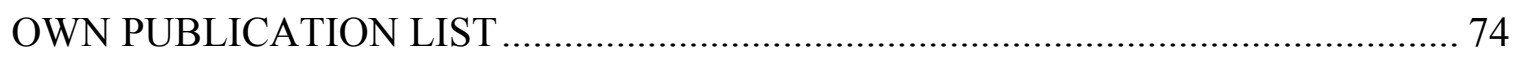

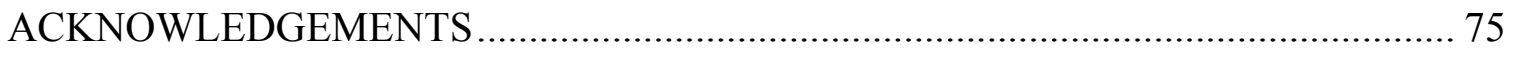

APPENDIX A (INFORMED CONSENT FORM)……………….......................... 76

APPENDIX B (BASIC ANATOMY AND PHYSIOLOGY OF SKELETAL MUSCLE

TISSUE \&INDICES OF SKELETAL MUSCLE DAMAGE)........................................ 81 


\section{LIST OF ABBREVIATIONS}

EE: Eccentric Exercise

MAT: Maximum Torque Average

MVC: Maximum Voluntary Contraction

MIF: Maximum Isometric Force

ROM: Range of Motion

DOMS: Delayed Onset Muscle Soreness

CK: Creatine Kinase

LDH: Lactate Dehydrogenase

SCs: Satellite Cells

MRFs: Myogenic Regulatory Factors

RT PCR: Real Time Polymerase Chain Reaction

PCR: Polymerase Chain Reaction

GDF-8: Myostatin/Growth and Differentiation Factor-8

P21: Cyclin-dependent kinase inhibitor 1A

CDK2: Cyclin-dependent kinase 2

Mstn-/-: Myostatin Null 


\section{LIST OF FIGURES}

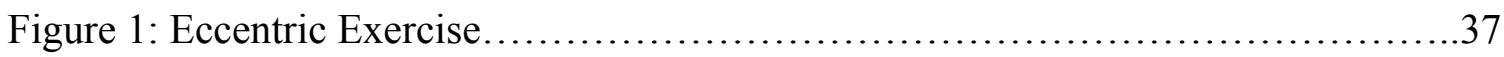

Figure 2: Muscle Biopsy................................................ 38

Figure 3: Experimental Design................................................

Figure 4: Delayed Onset Muscle Soreness............................................44

Figure 5: Maximum Torque Average.........................................44

Figure 6: Creatine Kinase and Lactate Dehydrogenase Activities.......................45

Figure 7: Muscle biopsy sections taken from the exercise group ..................47

Figure 8: Muscle biopsy sections taken from the control group..............................48

Figure 9: Muscle biopsy sections with direct evidence of muscle damage...................49

Figure 10: Relative MyoD, myogenin and myf5 mRNA expression....................51

Figure 11: Relative P21 and ki-67 mRNA expression.........................53

Figure 12: Relative Myostatin mRNA expression..................................54 


\section{CHAPTER I}

\section{INTRODUCTION}

One strange feeling that most of the times come unnoticed is that of a sore or damaged muscle. We have all experienced at some time the pain of a sore muscle while wondering what might be the reason for that. Well, skeletal muscle damage may occur as a result of acute trauma; extremely hot or cold temperatures; myotoxic agents such as snake toxins, cardiotoxin or notexin; ischemia; muscle diseases such as dystrophy; inflammation and skeletal muscle contractions. Although, all of the aforementioned reasons can cause muscle damage, the most usual reason is due to muscle contractions from an unaccustomed activity.

One of the earliest studies to introduced contraction-induced skeletal muscle damage was performed by Hugh et al. 1902. Hugh noted that following contractions of finger flexors until fatigue the muscle became sore. The soreness was not evident during the contractions but developed 8 to 10 hours later and peaked 48 to 72 hours afterwards. He suggested that muscle soreness was the result of muscle microtears.

In the last 20 to 30 years the interest in the subject of contraction-induced muscle damage increased dramatically such that numerous of studies have focused on the particular topic. Those studies have made a remarkable contribution in understanding the phenomenon of contraction-induced muscle damage.

It is now known that the contraction induced muscle damage is more pronounced and severe after eccentric contraction compared to any other type of contraction (Baker et al., 2006). An eccentric contraction occurs when the external load is far greater than the force produced by the muscle and thus skeletal muscle fibers are forced to lengthen. The increased probability of contraction-induced damage during an eccentric contraction relies on multiple factors. For example, based on Morgan's theory, during an eccentric contraction sarcomere length changes are highly non-uniform. Upon contraction some weak sarcomeres are "popped" (beyond myofillament overlap) while some others maintain their length or shorten. With repeated eccentric contractions the number of popped sarcomeres grows, until a point is reached where the cell membrane is ultimately 
disrupted (Morgan, 1990). In addition, eccentric contractions have been shown to invoke less EMG amplitude compared to any other contraction type (Linnamo et al., 2002; McHugh et al., 2000). Less EMG amplitude indicates that during an eccentric contraction a smaller cross-sectional area is activated to carry on an equivalent load, which in turns increases the mechanical stress imposed on the myofibers. Consequently, the possibility of contraction-induced muscle damage is greater during an eccentric contraction compared to concentric or isometric contraction.

An interesting feature of the contraction-induced muscle damage is the adaptation process. After the first bout of contraction-induced muscle damage, the repetition of an identical bout several days, weeks or even months later, significantly reduces the extent of muscle damage as compare to the first bout (McHugh, 2003; Nosaka et al., 2001). This phenomenon has been called Repeated Bout Effect and indicates that the first bout elicits an adaptation which provides a protective effect for the subsequent damaging bouts.

Even though the repeated bout effect reflects the high plasticity of skeletal muscle to adapt rapidly upon demands, it assumes that skeletal muscle has to recover fully. In practical situation, however, most athletes or even individuals have to continue their training plans prior fully recovery of their muscles. The thought that prevails, in such cases, is that continuation of exercise would cause even greater damage and thus athletes/individuals are encourage to stop exercise or exercise in a lower intensity. Interestingly, however, substantial evidence suggests that continuation of exercise prior fully recovery does not affect the ability of skeletal muscle to recover and neither exacerbates muscle damage (Nosaka and Clarkson, 1995; Chen and Hsieh, 2000; Paddon-Jones, 2000; Chen and Hsieh, 2001; Nosaka and Newton, 2002; Chen, 2003; Chen and Nosaka, 2006).

Although, such observations provide valuable information regarding the continuation of exercise with damaged muscle, are exclusively based on indirect markers of muscle damage. Any conclusion, based on indirect markers should be viewed with caution since several studies have showed that these markers do not really represent the actual damage of the muscle. For example leakage of myofibrillar proteins to the blood circulation 
which are commonly used indirect markers of muscle damage have been challenged by several studies who failed to report any relation between efflux of myofibrillar proteins and muscle damage(Komulainen et al., 1995; Nosaka and Clarkson, 1992). Accordingly, morphological evidence and direct quantification of skeletal muscle damage is necessary in order to clarify the appropriateness of exercise continuation with damaged muscles.

Despite the problematic usage of indirect markers of muscle damage and the fact that such investigations might have failed to determine the actual muscle damage, the impact of exercise continuation with damaged muscle on other physiological aspects is not elucidated yet.

Upon damage, muscle repair is exclusively accomplished by satellite cell (SCs) activation, proliferation and fusion (as myoblasts) with damaged sections of post-mitotic myofibers. The latter relies to the fact that skeletal muscle is a multinucleated tissue and each myonucleus regulates the transcriptional, translational and posttranslational events for a specific volume of cytoplasm (Rosser and Bandman, 2003; Rosser et al., 2002. Consequently as the demands for protein synthesis increases activation, proliferation and fusion of satellite cells are necessary in order to maintain a constant myonuclear domain (nucleus to cytoplasm ratio) that in turns would facilitate the needs for increased protein synthesis. SCs are mitotically quiescent muscle progenitor cells, located between the basal lamina and sarcolemma of mature myofibers (Mauro, 1961).

Several positive and negative growth factors have been shown to affect satellite cells activation and proliferation. The most commonly accepted positive factors are the hepatocyte growth factor and fibroblast growth factor while the most potent negative factor is Myostatin (GDF8) (Charge and Rudnicki, 2004). Since its identification 1997 (McPherron et al., 1997), growing evidence places myostatin a key protein in myogenesis since it appears to inhibit satellite cells activation (McCroskery et al. 2003), proliferation (Joulia et al. 2003) and differentiation (Joulia et al. 2003; Langley et al. 2002).

Once activated, however, specification of SCs to the myogenic lineage and subsequent terminal differentiation are critically dependent on myogenic regulatory factors (MRFs) (Megeny and Rudnicky 1995). MRFs, beyond their role in establishing the myogenic lineage (MyoD, Myf5) and terminal differentiation (myogenin, Myf6) of 
myoblasts, also regulate the expression of several muscle specific genes (Li and Capetanaki 1993; Lin et al. 1991; Wentworth et al. 1991).

The evolution in molecular biology techniques, offer nowadays the possibility to study the initial molecular response of a cell/tissue to an imposed stimulus. Consequently, by investigating the response of the aforementioned myogenic genes would further elucidate whether exercise continuation with damaged muscles is appropriate or not.

As noted we have all experienced at some time the feeling of a sore muscle after an unusual or unaccustomed activity. The question is, whether is proper to continue that particular activity/exercise before skeletal muscle recovery. Thus, the purpose of the present study is to study the impact of repeated bouts of eccentric exercise on several physiological aspects (mechanical, morphological, cellular-molecular) in order to determine the appropriateness of exercise continuation with "damaged" and/or affected muscles.

\subsection{Significance of the Problem}

Contraction-induced skeletal muscle damage, especially as a result of unaccustomed eccentric contractions, is a phenomenon that commonly excruciates athletes/individuals. Although in the last decades a remarkable effort has been made to understand this particular phenomenon a lot of issues remain to be elucidated. Particularly, there is little information regarding the continuation of exercise with damaged muscles. Evidence suggests that exercise continuation prior recovery do not exacerbate muscle damage and neither affects the ability of skeletal muscle to recover. This evidence, however, have been based on indirect markers of muscle damage the reliability of which have been challenged by several studies. Consequently, this issue to be resolved requires morphological evidence and direct quantification of muscle damage. Furthermore, there are no data, regarding the effects of exercise continuation prior full recovery, on other physiological aspects.

It is well known that once skeletal muscle is damaged, as a result of an unaccustomed eccentric exercise, requires approximately 10 days or more to recover. In practical situations, however, the resting interval needed for the skeletal muscle to recover is not always available because most of the training plans are performed more than once per 
week. Consequently, there is an emergent need to determine the effects and subsequently the appropriateness of exercise continuation with damaged muscles.

In order to provide a more complete picture, regarding the effects and appropriateness of exercise continuation prior recovery, we have designed an integrated study investigating several physiological aspects including mechanical, morphological, and cellularmolecular.

\subsection{Statement of the Problem}

The purpose of this study is to determine the effects of repeated-bouts of eccentric exercise for six consecutive days on the transcriptional alteration of myogenic (MyoD, Myogenin, Myf5, and Myostatin) and cell cycle (P21, Ki-67) regulatory genes as well as on the indirect (CK and LDH activity, torque-deficit, and DOMS) and direct (myofiber and sarcolemma damage) markers of skeletal muscle damage in a group of middle-aged untrained individuals.

\subsection{Delimitations of the study}

The results of the present investigation are confined within certain condition as the following delimitations we recognized:

1. The subject group consisted of 9 healthy, college-aged, untrained males.

2. The subject group was exercised in Biomechanics Laboratory at the Semmelweis University Faculty of Physical Education and Sport Sciences, in 2006.

3. The subject group performed 6 bouts of 15 unilateral eccentric contractions using their non-dominant knee extensors, for six consecutive days.

4. Each contraction was performed with the subject's maximum voluntary effort in a range of $120^{\circ}$ motion and $120^{\circ} / \mathrm{s}$ constant angular velocity. 
5. The subject group was exercised and tested for the biomechanical variables using a Multicont-II isokinetic dynamometer.

6. Skeletal muscle biopsies were taken under local anesthesia (1\% Lidocaine) by percutaneous needle biopsy using a 5-mm Bergström biopsy needle.

7. The middle portion of Vastus Lateralis muscle was used to determine Morphological and Molecular variables.

8. Blood samples were drawn from the antecubital vein in the laboratory of Sport Hospital, Budapest Hungary.

9. All blood and muscle biopsy samples were taken within an hour after the exercise protocol and always blood preceded muscle biopsy sampling.

10. All blood and muscle biopsies were taken after a fasting morning and always between 8:00 and 9:00 am.

\subsection{Limitations of the study}

The present investigation may be limited by the following factors:

1. The results of the present investigation are generalizable to: (i) untrained, collegeaged males, (ii) the particular training protocol utilized by the present investigation, (iii) the selected muscle and side of it (middle portion of Vastus Lateralis).

2. The subjects were instructed to perform Maximum Voluntary contractions during the exercise. Although, subjects were verbally encouraged throughout the exercise session to perform maximal voluntary contraction, it was beyond the abilities of the present study to control the subject's effort. 
3. At the days where the exercise was accompanied with a muscle biopsy, the subjects were instructed to attend the testing laboratory after a fast morning but it was beyond the abilities of the present study to control subject's diet.

4. Subjects were instructed to avoid any vigorous and /or intense activity during the experimental period; however, it was beyond the abilities of the present study to control subject's activities.

\subsection{Definition of terms}

The following definitions were used in this study:

Eccentric Exercise (EE). Eccentric exercise/contraction occurs when the contracting muscle is forcibly lengthened (Proske and Morgan, 2001).

Repeated Bouts of Eccentric Exercise: In the present study a "Bout" consist of six sets of fifteen repetitions. Repeated bouts referred to the repetition of the bout for six consecutive days.

Delayed onset muscle soreness (DOMS): DOMS is classified as a type I muscle strain injury and presents with tenderness or stiffness to palpation and/or movement (Cheung et al. 2003)

Real Time RT-PCR: A laboratory technique which combines real-time polymerase chain reaction with reverse transcription polymerase chain reaction. It is used to amplify low abundance messenger RNA, enabling quantification of relative gene expression at a particular time (http://en.wikipedia.org/wiki/Real-time polymerase chain reaction).

Isokinetic Dynamometer. A device that creates constant angular velocity. 


\subsection{Hypotheses}

Within the limitations of this study, the following research hypotheses will be tested at the .05 level of significance:

1. $\mathrm{H}_{0}$ : There will be no significant difference in Myostatin gene expression across the repeated measures.

2. $\mathrm{H}_{0}$ : There will be no significant difference in MyoD gene expression across the repeated measures.

3. $\mathrm{H}_{0}$ : There will be no significant difference in Myogenin gene expression across the repeated measures.

4. $\mathrm{H}_{0}$ : There will be no significant difference in Myf5 gene expression across the repeated measures.

5. $\mathrm{H}_{0}$ : There will be no significant difference in P21 gene expression across the repeated measures.

6. $\mathrm{H}_{0}$ : There will be no significant difference in Ki-67 gene expression across the repeated measures.

7. $\mathrm{H}_{0}$ : There will be no significant difference in skeletal muscle fibers morphology across the repeated measures.

8. $\mathrm{H}_{0}$ : There will be no significant difference in skeletal muscle fibers fibronectin staining across the repeated measures.

9. $\mathrm{H}_{0}$ : There will be no significant difference in mean Maximum-Average-Torque production across the repeated measures.

10. $\mathrm{H}_{0}$ : There will be no significant difference in $\mathrm{CK}$ activity across the repeated measures.

11. $\mathrm{H}_{0}$ : There will be no significant difference in LDH activity across the repeated measures.

12. $\mathrm{H}_{0}$ : There will be no significant difference in DOMS across the repeated measures. 


\section{CHAPTER II \\ REVIEW OF RELATED LITERATURE}

This chapter reviews the related literature and is divided in to four sections some of which have several subsections: Direct Indices of Skeletal Muscle Damage; Indirect Indices of Skeletal Muscle Damage; Muscle Regeneration Myostatin and MRFs; and Effect of Resistance Exercise on MRFs and Myostatin.

\subsection{Direct Indices of Skeletal Muscle Damage}

Skeletal muscle damage, as already mentioned, can be the result of multiple factors including contraction-induced skeletal muscle damage. The assessment and quantification of muscle damage can be performed either directly or indirectly. Direct assessment, assumes tissue collection and direct quantification of skeletal muscle damage in either structural or ultrastructural level. In the structural level, indices of skeletal muscle damage include: myofiber damage, damage to the muscle cell membrane (sarcolemma), partial or total myofiber necrosis, signs of inflammation and degeneration such as infiltration of mononuclear cells, and signs of regeneration such as centrally located myonuclei. In ultrastructural level, damage is characterized by disturbances on the contractile apparatus (actin and myosin); disturbances on the myofiber cross-striated band pattern (myofibrillar Z-discs streaming, broadening, or total disruption); disturbances on the myofibrillar endosarcomeric cytoskeleton (titin and nebulin), exosarcomeric cytoskeleton (desmin, vimentin, and synemin).

Following different histological or immunohistochemical staining procedures, the aforementioned structural and ultrastructural damage indices can be observed by light and electron microscopy respectively. In order to facilitate reading, the major morphological indices of muscle damage are shown in pictures (Appendix B) together with the basic, skeletal muscle, anatomy and physiology. 


\subsubsection{Direct Evidence for Eccentric Contraction-Induced Muscle Damage}

Among the three types of contraction (isometric, concentric and eccentric contraction), it has been shown that the probability of contraction induced muscle damage is greater during an eccentric contraction. For example Baker et al. 2006 found that, in rats, exercise involving eccentric contractions (15 sets of 10 stretch-shorteningcycles) can induce significantly more skeletal muscle damage compared to isometric contractions exercise of the same stimulation duration.

One of the earliest studies to show direct evidence of skeletal muscle damage, in humans, following eccentric exercise was performed by Friden et al 1983. In that study, 12 subjects performed a bout of eccentric bicycle (60 rpm for 30min) and open muscle biopsies were obtained from 5 subjects prior the exercise, immediately after, 3 days, and 6 days following the eccentric exercise bout. In ultrastructural level, disturbances of the cross-striated pattern were observed originated from the myofibrillar Z-band which showed marked streaming, broadening and in some cases total disruption. The disturbances were found in every third fiber up to 3 days after exercise and in one tenth of the fibers 6 days following the exercise. It is important to note here that the disturbances were observed only in ultrastructural level because the overall fiber morphology as seen with light microscope was absolutely normal with no morphological fiber abnormality in any of the sections. The ultrastructural disturbances, however, as seen with electron microscope were predominantly localized in type 2 fibers. The study concluded that eccentric exercise influences, selectively with regard to fiber type, the fine structure of the contractile apparatus.

In agreement with Friden et al. 1983, ultrastructural disturbances were observed by Hortobagyi et al. 1998. Twelve subjects performed 100 eccentric contractions with the quadriceps muscle and repeated the same exercise 2-weeks after the first exercise bout. Needle muscle biopsies were obtained from the distal portion of vastus lateralis before each exercise bout; two and seven days post the exercise bouts. Two days following the first exercise bout, electron microscopy revealed substantial disorganization of the myofillaments, widening if Z-lines, and Z-line streaming whereas seven days later no abnormality was observed. The same disturbances were observed two days after the 
second exercise bout (two-weeks later) while no disturbances were observed seven days after the second exercise bout.

Muscle damage, as a result of an unaccustomed eccentric exercise, is a process involving an initial and a secondary damage. The initial damage is predominantly a mechanical damage to individual sarcomeres while the secondary damage involves an acute inflammatory response and is a consequence of the initial injury. One of the earliest indices of muscle damage is the cytoskeleton disruption and particularly the loss of desmin intermediate filament. Lieber et al. 1996 found that the desmin intermediate filament is lost within 15 minutes after a single bout of eccentric contraction $(5,15$, or 30 minutes resulting 150-900 eccentric contractions), in Zealand White Rabbits. The results showed that control animals (passively stretch or isometrically exercised) had normal fiber morphology while in the eccentrically exercised group the fibers appeared large, rounded, partially or totally negative for desmin and unable to exclude plasma fibronectin.

In agreement with Lieber et al. 1996 results, Friden et al. 1998 also found that the earliest manifestation of muscle damage is the loss of desmin intermediate filament, in New Zealand White rabbits that were exercised eccentrically (900 eccentric contractions in 30 minute period).

Qualitative loss of desmin intermediate filament after eccentric exercise was also found by Barash et al 2002, in Male Sprague-Dawley rats after a single bout of 30 eccentric contractions; however, they also found a quantitative increase 72-168 hour.

Beyond the loss of desmin, another very early index of muscle damage is the loss of sarcolemma integrity. Lovering et al. 2004 found that 15 minutes after a single eccentric contraction the sarcolemma integrity was lost in $55 \%$ of the fibers. A single eccentric contraction was performed on the Tibialis Anterior muscle of Male Sprague-Dawley rats at $900^{\circ} / \mathrm{s}$ throughout a $90^{\circ}$-arc of motion. To evaluate sarcolemma integrity Evans Blue Dye was injected intraperitoneal 24 hours before animal were scarified. An interesting finding was that all fibers positive for Evans Blue Dye had discontinue or lost dystrophin organization and lost of desmin intermediate filament. The study concluded selective dystrophin vulnerability after a single eccentric contraction. 
The earliest abnormality observed by Komulainen et al 1998, was discontinuous dystrophin staining while at the same time no alterations occurred in the sarcolemma integrity and the staining of desmin and actin of Male Wistar rats that were subjected to 240 forced lengthening contractions.

Even though, form the above mentioned studies, it is not clear which is the earliest event; it seems that the case is most probably the loss of sarcolemma integrity. This is based to the fact that sarcolemma disruption will result in the loss of calcium homeostasis. Loss of $\mathrm{Ca}^{++}$homeostasis and particularly, intracellular elevation of free cytosolic $\mathrm{Ca}^{++}$will activate a number of $\mathrm{Ca}^{++}$-depended proteolytic and phospholipolytic pathways which respectively degrade contractile and membrane phospholipids leading to myofiber damage and necrosis (Armstrong et al 1991).

After the initial damage to myofibers, phagocytes and macrophages infiltrate the damaged myofibers and initiate an acute inflammatory response. The inflammatory response, that usually commences 1 to 3 days after the initial injury, is the primary reason for the secondary injury. The infiltrated phagocytic cells remove the damaged myofibrils, cytosolic organelles, and sarcolemma leading to total muscle fiber degeneration and thereby the initial damage is aggravated.

\subsubsection{Direct Evidence against Eccentric Contraction-Induced Muscle Damage}

Form the above mentioned studies the existence of the eccentric contraction inducedmuscle damage, in animals, can be clearly documented. In addition no contradictory findings have been published considered the effectiveness of eccentric exercise to induce muscle damage. In humans, however, despite the significantly less direct evidence supporting the contraction-induced muscle damage; evidence supports that human's skeletal are not prone to eccentric contraction induced-muscle damage or at least the severity of damage is less than that observed in animals.

$\mathrm{Yu}$ et al. (2002) found no loss of desmin, no sarcolemma damage; and any myofiber degeneration, inflammation or necrosis after a single bout of downstairs running, eccentric bicycling or downhill treadmill running. In that study the subjects were exercised eccentrically by either downstairs running (from the tenth floor to the ground floor for 15 times), eccentric bicycling (60 rpm for 30 minutes), or downhill treadmill 
running ( $8^{\circ}$ decline for 45 minutes). The results showed that all muscle biopsies taken before and after each exercise type at various time points (up to 8 days after the exercise) showed normal fiber appearance with no loss of desmin, no sarcolemma damage; and any myofiber degeneration, inflammation or necrosis. The authors concluded that, in humans, eccentric exercise does not cause loss of desmin nor myofibre necrosis.

Crameri et al. (2004), in agreement with Yu et al. 2002, showed no muscle damage in seven of eight subjects that performed a single bout of 210 maximum voluntary eccentric contractions. Needle muscle biopsies were collected before, 2, 4, and 8 days after the exercise bout and stained with hematoxylin and eosin, desmin, fibronectin, and CD68 (macrophages marker). In seven of eight subjects the result showed, no evidence of gross myofiber damage, no myofiber necrosis, no positive staining for CD68, no loss of desmin staining and no fibronectin staining inside the muscle fibers. Only one subject showed myofiber necrosis, fibronectin positive myofibers and loss of desmin staining, all of which commenced at day 2 and were not fully recovered at day 8 .

\subsection{Indirect Indices of Skeletal Muscle Damage}

In contrast with animal studies, direct quantification of skeletal muscle damage in humans' can only be assessed through the analysis of muscle biopsy samples and therefore is a difficult if not unpleasant procedure for the study's subjects. Due to the invasive nature of muscle biopsy, investigators usually avoid muscle biopsies and utilize "indirect markers of muscle damage" in order to assessed the presence and/or the degree of muscle damage. Indirect indices are named so because they do not offer direct evidence of muscle damage but are rather a consequence of it. They include strength deficit, muscle soreness that is delayed onset, leakage/efflux of myofibrillar proteins to the blood, muscle swelling and decreased pain-free range of motion.

DOMS, muscle swelling and decreased pain-free range of motion are not specific but are rather general markers of muscle damage and inflammation. However, there are some indirect markers that are used specifically to infer damage to different muscle structures. 
For example, under normal circumstances, the activity of myofibrillar proteins in the blood is low. Consequently, leakage/efflux of myofibrillar proteins to the blood can reflect damage to the sarcolemma as well as damage/disruption of the particular protein.

Strength deficit, on the other hand, can reflect damage to force-generating structures (contractile apparatus actin and myosin) and/or damage to force-transmitting structures such as sarcolemma and desmin intermediate filament.

\subsubsection{Indirect Evidence for Eccentric Contraction-Induced Muscle Damage}

Single bout of eccentric exercise: It is well documented that a single bout of eccentric exercise results in the appearance of the indirect indices of muscle damage. For example, Lee et al. 2002 showed indirect evidence of muscle damage after a single bout of eccentric exercise. In that study, eight untrained healthy males performed 60 eccentric contractions at approximately $135-150 \%$ dominant arm maximum isometric force (MIF) using their nondominant arm elbow flexors. Plasma CK activity, DOMS, range of motion (ROM), MIF, and blood were obtained before, immediately after, and 24, 48, 72, and 96 $\mathrm{h}$ after the EE.. Plasma CK activity peaked at $72 \mathrm{~h}$ compared with the baseline. A significant decrease in MIF occurred at all times after the EE. ROM decreased from 24 to $96 \mathrm{~h}$, and DOMS increased 24 to $72 \mathrm{~h}$ in the nondominant arm. The authors suggested eccentric exercise induced-muscle damage, since all indirect indicators of muscle damage changed significantly after the exercise. Following a single bout of voluntary eccentric muscle contractions, Brown et al. 1997 also showed indirect evidence of exerciseinduced human skeletal muscle damage as well as connective tissue breakdown.

There are numerous of studies showing indirect evidence of skeletal muscle damage. From those studies it appears that the degree of muscle damage, as assessed by the indirect indices, varies among muscle groups and depends on different factors such as exercised range of motion, velocity and intensity. For example, Jamurtas et al. 2005 found that the magnitude of muscle damage was greater in elbow flexors than in knee extensors. McHugh and Pasiakos 2004 showed that the degree of muscle damage depends on the exercising muscle length. Chapman 2006 showed that the contraction velocity is another determinant factor that affects the degree of muscle damage, since, for 
the same time under tension; fast velocity eccentric exercise caused greater muscle damage than slow velocity exercise in untrained subjects.

The Repeated bout Effect: As can be deduced from the above mentioned studies a single bout of eccentric exercise results in the appearance of indirect markers of muscle damage. An interesting feature of the contraction-induced muscle damage is the adaptation process. After the first bout of contraction-induced muscle damage, the repetition of an identical bout several days, weeks or even months later, significantly reduces the extent of muscle damage as compare to the first bout. This phenomenon has been called Repeated Bout Effect and indicates that the first bout elicits an adaptation which provides a protective effect for the subsequent damaging bouts.

McHugh et al. (2003) reviewed approximately twenty studies with varying intensity, delay between bouts and exercised muscle group all of which have demonstrated the existence of repeated bout effect.

In a later study Cleary et al. (2002) also demonstrated the existence of the repeated bout effect on DOMS. Sixteen male and fifteen female untrained subjects performed two identical eccentric exercise bouts, using their wrist extensor muscles, each of which consisted of 5 sets of 50 repetitions and separated by either $6,7,8$, or 9 weeks. DOMS was measured by perceived analogue scale and punctuate tenderness gauge. Perceived pain and muscular tenderness were significantly less after the second bout of exercise than after the first exercise bout for all exercise groups. It was concluded that an effective prophylaxis for perceived pain and muscular tenderness associated with DOMS is the performance of an eccentric exercise bout 6 to 9 weeks prior to a similar exercise bout.

Nosaka et al. (2001), investigated whether the repeated bout effect can even lasts when the delay between exercise bouts is very large. Thirty five untrained males were placed into three groups and using their non dominant elbow flexors performed two bouts eccentric exercise each of which consisted of 24 contractions and separated by either 6,9 or12 months. All indirect markers of muscle damage measured were attenuated when the second exercise bout performed 6 or 9 months following the first exercise bout, however no repeated bout effect was observed when the second bout was perform at 12 months.

Multiple bouts of Eccentric Exercise prior full recovery: As noted, after a single bout of eccentric exercise, the indirect indices of muscle damage commence few hours 
after the damaged contraction, peak 48 to 72 hours later and return to the normal levels approximately 10 days afterwards. However, the well documented existence of the Repeated Bout Effect and the protective effect on the indicators of muscle damage have raised the question whether such an adaptation occurs prior full recovery of skeletal muscle. That is, regardless the imposition of a second exercise bout prior full recovery, the question was whether skeletal muscle was able to adapt by avoiding exacerbation of muscle damage indices.

One of the earliest studies to examine the latter question was performed by Nosaka K. and Clarkson PM. (1995). Twelve untrained males performed three sets of 10 eccentric actions of the elbow flexors using $80 \%$ of the pre-exercise maximal isometric force level. The same exercise was repeated 3 and 6 days after the first exercise. MIF, ROM, DOMS, plasma CK and Glutamic-Oxaloacetic Transaminase were measured before exercise bout one, after each exercise bout and three days after exercise bout three. DOMS was measured before exercise bout one and thereafter every day for nine days. All criterion measures changed significantly following exercise bout one. However when the same exercise performed three and six days after exercise bout one none of the criterion measured changed significantly even though the second and third bout was performed prior fully recovery. It was concluded that strenuous exercise performed with damaged muscle did not exacerbate damage or affect the recovery process.

Chen TC and Hsieh SS (2000) performed a follow-up study having one main difference from Nosaka K. and Clarkson PM. (1995) study. The exercise intensity was Maximal voluntary contractions instead of $80 \%$ of the pre-exercise MIF used by Nosaka (1995). The purpose of the study was to investigate whether performing repeated bouts of maximal voluntary isokinetic eccentric exercise three and six days after the initial bout would produce significant changes in the indirect markers of muscle damage. Twelve untrained males were in the control group that performed a single bout of eccentric exercise consisted of 3 sets of 10 eccentric contractions using the non dominant elbow flexors. The exercise group $(n=12)$ performed the same exercise three and six days following the initial bout exercise. The study reported no significant changes between the groups with the exception of total work that was significantly decreased in the repeated bout group. In agreement with Nosaka K. and Clarkson PM. (1995) the study concluded 
that strenuous voluntary isokinetic exercise performed with damaged muscles does not appear to exacerbate damage or influence the recovery process.

Another study by Paddon-Jones D. et al. (2000) examined the same question however the repeated bout was performed two days following the initial exercise bout. The study concluded that when maximal isokinetic eccentric exercise is repeated two days after experiencing contraction-induced muscle injury the recovery time course is not significantly altered.

Nosaka K. and Newton M. (2002), examined whether performing repeated bouts of eccentric exercise two and four days after the initial damaging bout would exacerbate muscle damage indices. Nine non trained males performed 3 sets of 10 eccentric contractions with the elbow flexors using $50 \%$ of their MIF at $90^{\circ}$. Two weeks later the same subjects perform the same exercise with the opposite arm and that was repeated after two and four days. No significant differences in changes in MIF, ROM, DOMS and plasma CK were observed between the single and the repeated bout groups.

Most of the studies examining the effects of repeated eccentric exercise prior fully recovery, have used, as can be seen from the aforementioned studies, untrained subjects. Chen TC and Nosaka K (2006) examined the same question but recruited athletes for subjects. Fifty-one athletes (41 males and 10 females) were randomly assigned to either control $(n=12), 100 \%(n=12), 90 \%(n=13)$, or $80 \%(n=14)$ group. All groups performed an initial exercise bout consisting of 30 eccentric contractions of the elbow flexors using a dumbbell weighted $100 \%$ of the MIF at the elbow joint angle of $90^{\circ}$. Three days later, with the exception of control group, all groups repeated the same exercise but the intensity was adapted to 100,90 , or $80 \%$ of the first exercise bout. The results showed that regardless of the group all variables changed significantly after the initial bout however no significant changes were apparent between groups for any variable after the second exercise bout. The authors suggested that athletes can perform high -intensity eccentric exercise in the early stage of recovery from the initial bout. It was concluded that by performing a subsequent bout of eccentric exercise three days after the first do no cause further damage to the elbow flexors.

From the above mentioned studies the question whether an adaptation effect was evident prior fully recovery from the initial exercise bout was becoming fact. There after 
researchers tried to identify whether this adaptation effect is still evident under more strenuous situations.

For doing so, Chen TC (2003) increased the number of contractions to more than double for the repeated bout group. Twenty six non trained males were randomly assigned to a control $(n=9)$, experimental-30 $(n=8)$ and experimental-70 $(n=9)$ group. All groups perform an initial exercise bout consisting of 30 maximal voluntary isokinetic contractions using their non dominant arms. Three days after the initial bout the experimental-30 and 70 groups perform a second bout of exercise consisting of 30 and 70 eccentric contraction respectively. All indicators of skeletal muscle damage change significantly following the initial bout of exercise but no additional changes were observed after exercise bout two for either experimental-30 or 70 groups. The study concluded that performing repeated bout of eccentric exercise prior fully recovery do not exacerbates muscle damage, even when the repeated bout is more strenuous.

In an earlier study Chen TC and Hsieh SS (2001) scheduled an even more strenuous exercise protocol where maximal voluntary isokinetic eccentric exercise was repeated for seven consecutive days and thus allowing only $24 \mathrm{~h}$ rest for the skeletal muscle to recover.

The results showed that continuous isokinetic eccentric exercise performed with damaged muscle did not exacerbate muscle damage and inflammation. In addition the authors suggested that an adaptation effect may occur as early as $24 \mathrm{~h}$ following the initial "unaccustomed exercise".

\subsubsection{Indirect Evidence against Eccentric Contraction-Induced Muscle Damage}

Although no study has challenged the appearance of indirect indices of muscle damage following eccentric exercise, some studies have challenged their reliability. That is, some studies support that the indirect indices of muscle damage, particularly leakage of myofibrillar proteins to the blood circulation, do not really represent the actual muscle damage.

Komulainen et al 1995 found no relation between muscle damage and CK activity after exercise in rats. In that study, rats were separately exposed to one-hour swimming, combination of one-hour swimming and one-hour running, or one-hour running protocol. Blood serum was then repeatedly analyzed over a period of $72 \mathrm{~h}$ for CK activity, while 
their soleus and quadriceps femoris muscles were excised and analyzed for betaglucuronidase activity (damage marker) $72 \mathrm{~h}$ after the commencement of the experiment. The results clearly showed that serum CK activity may increase without concomitant muscle damage (swimming protocol) and that muscle damage may occur without a statistically significant increase in serum CK activity (running protocol). The authors concluded that serum CK activity is an inadequate indicator of muscle damage both quantitatively and qualitatively.

Similar findings were reported also by Nosaka et al. 1992. That study investigated whether a larger post-exercise increase in CK activity would be produced when a larger amount of muscle is damaged by eccentric exercise. Twenty-two untrained females were placed into two groups; Group A $(\mathrm{n}=12)$ and Group B $(\mathrm{n}=10)$. The right and left arm were exercised on the same day for Group A (24 eccentric actions per arm, a total of 48 actions). In contrast, Group B performed 24 actions with either the right or the left arm on the first bout and performed 24 eccentric actions with the opposite arm on the second bout 3-5 weeks later. Blood samples were taken before and for 5 days after each exercise and plasma CK activity was determined. No significant differences were observed in the pattern of change and the peak of CK values between group A and group B. It was expected that Group A (two arms were exercised on the same day) should show an approximate two-fold increase in plasma CK compared to Group B when one arm was exercised on each bout. Based on the latter observation the authors concluded that postexercise CK activity does not reflect muscle mass involved in the exercise and neither the extent of muscle damage.

\subsection{Muscle Regeneration, Myostatin and MRFs}

Skeletal muscle has a remarkable capacity to adapt up on demands such as during growth and damage stimulus. This high plasticity of skeletal muscle is largely attributed to the satellite cells. Satellite cells are mitotically quiescent muscle progenitor cells, located between the basal lamina and sarcolemma of mature myofibers. Once activated, 
satellite cells, proliferate, differentiate and fuse to form new myofibers, repaired the damaged one, or give additional myonuclei to the enlarging fibers.

\subsubsection{Myogenic Regulatory Factors}

At the molecular level activation, proliferation and differentiation of satellite cells is characterized by the upregulation of Myogenic Regulatory Factors (MRFs). MRFs are skeletal muscle-specific transcription factors. The family consists of MyoD, myogenin, Myf5, MRF4 and belongs to a larger basic-helix-loop-helix (bHLH) class of transcription factors. In the course of muscle regeneration and/or growth satellite cells are activated, exit their quiescent state, and start proliferating. Proliferating satellite cells are usually referred to as myoblasts. Quiescent satellite cells do no have any detectable levels of MRFs but specification of satellite cells to the myogenic lineage requires the upregulation of the early MRFs, MyoD and Myf5. After several round of proliferation, proliferating myoblasts, withdraw from the cell cycle to become terminally differentiate myocytes. At the stage of differentiation myocytes express the late MRFs, myogenin and MRF4, and subsequently muscle specific genes such as creatine kinase, troponin, and myosin heavy chain.

The importance of myogenic regulatory factors in muscle regeneration was documented by several studies, whereas their expression was induced upon damage. For example Daniel et al. 1997 investigated the mRNA expression of MRFs during muscle regeneration following bupivacaine injection in young, adult, and old rats (Fischer 344/Brown Norway F1 rats aged 3, 18, and 31 mo of age respectively). The results showed that MyoD and myogenin mRNA were increased in muscles of young, adult, and old rats 5 days after bupivacaine injection. Thereafter MyoD decreased to control levels by day 14 in young and adult rats, and remained elevated in the old rats for 28 days. Myogenin was still significantly increased 14 days post injection in all groups, then

declined to control level for young rats while adult and old rats had an increased myogenin mRNA up to 28 and 21 days respectively.

In addition Mendler et al. 1998 also found increased MRFs mRNA levels in rat soleus (slow) and extensor digitorum longus (fast) during regeneration. In that study, after notexin injection to induce muscle damage MyoD, myf5, myogenin and MRF4 were 
measured by RT PCR in rat soleus and extensor digitorum longus at different time points $(1,3,5,7,10,21$, and 28 day). For both muscles, the MyoD mRNA was up-regulated on the first day after administration of the toxin and then peaked at 3 and 5 day in soleus and extensor digitorum longus respectively. Myf5 mRNA disappeared in the first day but showed a substantial increase in later stages of regeneration (3, 5, 7 days in both muscles). The mRNA levels of the late MRFs myogenin and MRF4 decreased on day one only in the soleus, then increased on day 3 in both muscles. Meanwhile in extensor digitorum longus the level of MRF4 mRNA remained relatively normal. Four weeks after administration of the toxin the mRNA levels for each of the MRFs returned to nearly control levels. This shows that the level of MRF transcripts changed according to a quite predictable pattern; the upregulation corresponded to myoblast activation and the downregulation to the reinnervation.

\subsubsection{Myostatin}

Beyond MRFs, Myostatin is another crucial factor in the course of muscle regeneration and/or growth. Myostatin, identified by McPherron et al. 1997, belongs to the transforming growth factor-beta (TGF-beta) superfamily and has been initially termed Growth and Differentiation Factor-8 (GDF-8). Myostatin is produced in skeletal muscle cells, circulates in the blood and acts on muscle tissue, apparently by inhibiting satellite cells activity.

Thomas et al. 2000 showed that myostatin inhibits myoblasts proliferation by arresting them in the $\mathrm{G}_{1}$-phase of the cell cycle. When $\mathrm{C}_{2} \mathrm{C}_{12}$ myoblasts were incubated with myostatin (0-10 $\mu \mathrm{g} / \mathrm{ml}$ recombinant myostatin), proliferation of myoblasts decreased with increasing levels of myostatin. Fluorescence-activated cell sorting analysis revealed that myostatin prevented the progression of myoblasts from the $\mathrm{G}_{1}$ - to S-phase of the cell cycle. Western analysis indicated that myostatin specifically up-regulated p21, a cyclindependent kinase inhibitor, and decreased the levels and activity of Cdk2 protein in myoblasts. The authors proposed that the generalized muscular hyperplasia phenotype observed in animals that lack functional myostatin could be as a result of deregulated myoblast proliferation. 
In a later study Langley et al. 2002 showed that myostatin is an inhibitor of myoblast differentiation. Increasing concentrations of recombinant mature myostatin reversibly blocked the myogenic differentiation of myoblasts, cultured in low serum media. Western and Northern blot analysis indicated that addition of myostatin to the low serum culture media repressed the levels of MyoD, Myf5, myogenin, and p21 leading to the inhibition of myogenic differentiation. The transient transfection of $\mathrm{C}_{2} \mathrm{C}_{12}$ myoblasts with MyoD expressing constructs did not rescue myostatin-inhibited myogenic differentiation. The authors proposed that myostatin plays a critical role in myogenic differentiation and that the muscular hyperplasia and hypertrophy seen in animals that lack functional myostatin is because of deregulated proliferation and differentiation of myoblasts.

McCroskery et al. 2003 showed that myostatin inhibits also satellite cell activation. BrdU labeling in vivo revealed that, among the Myostatin-deficient satellite cells, higher numbers of satellite cells are activated as compared with wild type. Cell cycle analysis, in satellite cells, showed that Myostatin up-regulated p21 and decreased the levels and activity of Cdk2 protein. The study concluded that myostatin negatively regulates the G1 to $\mathrm{S}$ progression and thus maintains the quiescent status of satellite cells.

The inhibitory effects of myostatin on satellite cells activity, as can be deduced from the aforementioned studies, indicate that skeletal muscle regeneration is partly accomplished by downregulating myostatin.

The first study to investigate the alteration of myostatin protein during muscle regeneration was performed by Kirk et al 2000. In that study, in order to induce muscle damage, normal Sprague-Dawley and growth hormone-deficient rats were injected by notexin in the right biceps femoris on day 0 . The biceps femoris of Normal and growth hormone-deficient rats were dissected on days 1, 2, 3, 5, 9 and 13, formalin-fixed, then immunostained for myostatin protein. Immunostaining for myostatin revealed high levels of protein within necrotic fibers and connective tissue of normal and growth hormonedeficient damaged muscles. Regenerating myotubes contained no myostatin at the time of fusion (peak fusion on day 5), and only low levels of myostatin were observed during subsequent myotube enlargement. Fibers which survived assault by notexin (survivor fibers) contained moderate to high myostatin immunostaining initially. The levels in both normal and growth hormone-deficient rat survivor fibers decreased on days 2-3, and then 
increased on days 9-13. The authors suggested a negative regulatory role for myostatin in muscle regeneration due to the low level of myostatin observed in regenerating myotubes.

Armand et al. 2003 showed decreased myostatin mRNA during soleus muscle regeneration. That study analyzed in mouse, by using in situ hybridization, the spatial and temporal expression patterns of myostatin and follistatin mRNAs during soleus regeneration after cardiotoxin injury. In addition, the study aimed to investigate the influence of innervation on the accumulation of these two transcripts. The results showed Follistatin transcripts could be detected in activated satellite cells as early as the first stages of regeneration and were transiently expressed in forming myotubes. The myostatin mRNA levels fell in the necrotic fibers (up to 5 days post injection) before being up-regulated in the subsequent stages of muscles regeneration. Muscle denervation persistently reduced the levels of myostatin transcripts as early as the young myotube stage, whereas the levels of follistatin mRNA were strongly increased in the small myotubes in the late stages of regeneration. These results showed the potential functions of both follistatin, as a positive regulator of muscle differentiation, and myostatin, as a negative regulator of skeletal muscle growth.

Decreased myostatin mRNA expression was also observed by Mendler et al. 2000, early after myotoxin induced muscle damage. However, despite the low mRNA expression, Mendler et al. 2000 observed a dramatic increased in myostatin protein levels.

In contrast to Mendler et al. 2000 findings, Shibata et al. 2006 after frostbite induced muscle damage, in the semitendinosus muscle of Japanese Black Cattle (age of 16 month), found decreased myostatin protein as well as mRNA expression.

Myostatin, as noted, acts to keep Satellite Cells in a quiescent state. One the other hand muscle regeneration is exclusively accomplished by activation, proliferation, differentiation and fusion of Satellite Cells. Consequently, in the absence and/or inhibition of myostatin, one would assume enhanced muscle regeneration. This appears to be true from studies that have examined, in animals, muscle regeneration in the absence of myostatin. 
McCroskery et al. 2005 found enhanced muscle regeneration in myostatin-null (Mstn-/-) mice as compared with the wild-type mice.

Wagner et al. 2005 also showed enhanced regeneration in the absence of myostatin. After cardiotoxin injury the tibialis muscle from senescent 24-month-old $\mathrm{mstn}^{-/-}$animals retain the ability to regenerate. MyoD and Myf4 mRNA were enhanced and Satellite Cells in $\mathrm{mstn}^{-/-}$animals proliferate and differentiate more rapidly than satellite cells from wild type animals. Seven days after injury, $\mathrm{mstn}^{-/-}$muscle attained $43 \%$ larger myofibers diameter than wild type. The study concluded that in the absence of myostatin, early markers of regeneration are enhanced. In addition, Bogdanovich 2005 demonstrated that neutralization of myostatin leads to increased muscle regeneration in Duchenne's muscular dystrophy such that body weight, strength, and muscle mass were significantly increased in treated mice compared with controls.

\subsection{Resistance Exercise, MRFs and Myostatin}

Compensatory hypertrophy involve two main processes: The first is an anabolic process necessary for protein accretion to support myofiber enlargement. The second involves activation proliferation and fusion of satellites cells which is necessary in order to provide additional myonuclei to the enlarging myofibers. The latter relies to the fact that skeletal muscle is a multinucleated tissue and each myonucleus regulates the transcriptional, translational and posttranslational events for a specific volume of cytoplasm. Consequently as the demands for protein synthesis increases activation, proliferation and fusion of satellite cells are necessary in order to maintain a constant myonuclear domain (nucleus to cytoplasm ratio) that in turns would facilitate the needs for increased protein synthesis.

It is well documented that resistance exercise, when performed 2-3 days/wk for several weeks, is a potent stimulus for compensatory hypertrophy. Compensatory hypertrophy, however as noted, requires increased activity of satellite cells as well as increased expression muscle specific genes. Since MRFs and Myostatin have an important role in the activity of satellite cells it can be deduced that these proteins, beyond muscle regeneration, are also crucial in the course of muscle growth. 


\subsubsection{Myogenic Regulatory Factors}

In accordance with their importance in compensatory hypertrophy, several studies found upregulation of MRFs following resistance training. Psilander et al (2003), investigated whether a bout of heavy-resistance training would affect the MRF and IGF-I mRNA levels in human skeletal muscle. Six male subjects completed four sets of 6-12 repetitions on a leg press and knee extensor machine separated by $3 \mathrm{~min}$. Myogenin, MRF4, and MyoD mRNA levels were determined in the vastus lateralis muscle by RTPCR before exercise, immediately after, and 1, 2, 6, 24, and $48 \mathrm{~h}$ post-exercise. Myogenin, MyoD, and MRF4 mRNA levels were elevated by 100-400\% 0-24 h postexercise. Based on the results the authors suggested that myogenin, MyoD, and MRF4 mRNA levels are transiently elevated in human skeletal muscle after a single bout of heavy-resistance training, supporting the idea that the MRFs may be involved in regulating hypertrophy and/or fiber-type transitions.

In a most recent study Yang et al. (2005), examined the time course activation of all MRFs (MRF4, Myf5, MyoD, myogenin) genes after an acute bout of resistance exercise. Six relatively trained subjects performed a bout of resistance exercise which consisted of 3 sets of 10 knee extensions, on isokinetic dynamometer, at $70 \%$ of concentric onerepetition maximum. Eight muscle biopsies were taken from the vastus lateralis muscle before, immediately after, and 1, 2, 4, 8, 12 and $24 \mathrm{~h}$ after exercise. Resistance exercise increased mRNA of MRF4 (3.7- to 4.5-fold 2-4 h post), MyoD (5.8-fold $8 \mathrm{~h}$ post), and myogenin (2.6- and 3.5-fold 8-12 h post). The timing of the gene induction was variable and generally peaked $4-8 \mathrm{~h}$ post-exercise with all gene expression not significantly different from the pre-exercise levels by $24 \mathrm{~h}$ post-exercise. In agreement with Psilander et al (2003), the results of Yang et al. (2005) study showed that a single-bout of resistance exercise stimulates a transient expression of MRFs.

Raue et al. (2006), investigated the expression of MRFs, Myostatin and myocyte enhancer factor 2 at rest and $4 \mathrm{~h}$ after a single bout of resistance exercise in young and old women. Eight young women and six old women performed 3 sets of 10 repetitions of bilateral knee extensions at $70 \%$ of one repetition maximum. Muscle biopsies were taken from vastus lateralis before and $4 \mathrm{~h}$ after exercise. The mRNA for the genes tested was amplified using real time RT-PCR. At rest, old women were found to express higher 
levels for MRFs and Myostatin compared with young women. In response to exercise, young women and old women up-regulated the expression of MyoD (2.0 fold) and MRF4 (1.4 fold) while the expression of Myostatin was suppressed (2.2 fold). The authors concluded that old women expression higher myogenic mRNA levels at rest. When challenged with resistance exercise, old and young women and respond in a similar manner by upregulating myogenic gene expression. In addition the author suggested that the higher resting myogenic mRNA levels in old women may reflect an attempt to preserved muscle mass and function.

Kim et al. (2005) also investigated whether resistance exercise would induce the expression of MRFs. The author hypothesized that the myogenic responses would be blunted in older males and females as compared to young adults. Young (20-35 yr, 10 young females and 10 young males) and Old (60-75 yr, 9 old females and 9 old males) subjects underwent vastus lateralis biopsy before and $24 \mathrm{~h}$ after knee extensor exercise. Resistance exercise consisted of three sets of 8-12 repetitions to volitional fatigue for each of three movements that load the knee extensors bilaterally (squat, leg press, and knee extensions). Transcript levels were assessed by relative RT-PCR. An increase in myogenin mRNA levels (53\%) was found $24 \mathrm{~h}$ after acute resistance loading. However pre-post loading changes within groups were noted in young males and young females only. A main loading effect indicated that levels of MyoD mRNA expression increased by $20 \% 24 \mathrm{~h}$ after acute resistance exercise. However, this was exclusive to young females and old males. Levels of myf-5 mRNA were not altered by resistance exercise. In addition, resistance exercise resulted in a small but significant $10 \%$ reduction in myf- 6 mRNA expression in all groups. The authors concluded that the attenuated MyoD and myogenin mRNA expression in old subjects following resistance exercise indicates an impair growth and/or regenerative capacity.

\subsubsection{Myostatin}

The aforementioned inhibitory effects of myostatin on satellite cells activity have raised the question, whether exercise-induced hypertrophy complements myostatin downregulation. However, to date, few studies have examined this problem and surprisingly contradictory findings have been published. 
For example Willoughby et al. 2004 found increased myostatin mRNA and protein after six and 12-weeks of resistance training. That study examined the effects of 12weeks resistance training on the mRNA and protein expression of myostatin, follistatinlike related gene, activin IIb receptor, cortisol, glucocorticoid receptor, myofibrillar protein, as well as the effects on muscle strength and mass and body composition. Twenty-two untrained males were randomly assigned to either a resistance-training $(\mathrm{n}=$ 12) or control group $(\mathrm{n}=10)$. Muscle biopsies and blood samples were obtained before and after 6 and $12 \mathrm{wk}$ of resistance training from the vastus lateralis. Resistance training was performed 3days/week and each session consisted of three sets of six to eight repetitions (85-90\% of one repetition maximum) using leg press and knee extension exercises. The study observed significant increases in myostatin mRNA, myostatin, follistatin-like related gene, cortisol, glucocorticoid receptor, and myofibrillar protein after 6 and 12 weeks of training. Also total body mass, fat-free mass, strength, and thigh volume and mass were also increased. Therefore the authors concluded that the increased myostatin in response to cortisol and/or resistance training have no effects on traininginduced increases in muscle strength and mass.

In contrast to Willoughby et al. 2004 findings, Roth et al 2003 found reductions in myostatin following 9-weeks of resistance training. That study examined myostatin mRNA changes in young (20-30 years; 4 men, 4 women) and old (65-75 years; 3men, 4 women) subjects who completed a 9-week heavy-resistance unilateral knee extension program. The training was performed 3 days/week and each session consisted of 50 near maximal resistance repetitions, of the dominant leg. Muscle biopsies were obtained from the dominant vastus lateralis before and by the end of the 9-week protocol. Myostatin mRNA was quantified using quantitative PCR by standard fluorescent chemistries and was normalized to $18 \mathrm{~S}$ rRNA levels. By the end of the 9-week resistance training protocol, the study observed a $37 \%$ decrease in myostatin expression was in all subjects. The decline in myostatin expression was similar regardless of age or gender. The authors suggested that myostatin mRNA levels are reduced in response to heavyresistance training in humans.

In the study of Kim et al. 2005, described above, myostatin mRNA decreased after a single bout of resistance training. Myostatin, declines were noted in young males $(-56 \%)$, 
young females $(-48 \%)$, and old males $(-40 \%)$, while no change was observed in old females. Based on the data the authors suggested that resistance training down-regulates myostatin expression. 


\section{CHAPTER III}

\section{METHODOLOGY}

\subsection{Selection of Subjects}

Fifteen healthy, untrained males [age 27.0 years (SD 10.1), weight $72.6 \mathrm{~kg}$ (SD 7.9), height $176 \mathrm{~cm}$ (SD 6.8)] were recruited for this study and randomly assigned to an experimental group $(n=9)$ or a control group $(n=6)$.

According to the selection criteria, none of the subjects had a history of knee injury and, at the time of the study, all were free of orthopaedic abnormalities. Additionally, for a period of six months prior to the study, subjects had not been involved in any resistance training, were completely free of muscle soreness and had not been used any antiinflammatory and/or other medication .

All subjects received verbal and written information prior to their participation concerning all aspects of the study and all possible complications in relation to the muscle biopsies. A written consent form was obtained from all subjects before participating. The study was performed in accordance with the Declaration of Helsinki (revised in 2000) and was approved by the Semmelweis University Research Ethics Committee. Finally, it should be mentioned that all subjects were compensated for their participation.

\subsection{Instruments and collection of data}

\subsubsection{Instruments and procedures for collecting biomechanical data and DOMS}

(i) Resistance exercise: All subjects attended the testing lab for six consecutive days. In each session, subjects had to complete six sets of 15 single leg maximum voluntary contractions (MVC), using their non-dominant knee extensors. These sessions lasted approximately 20 minutes, including rest intervals (1 min between sets). Prior to each exercise session, subjects performed a five min warm-up by cycling on an ergometer, followed by five min of stretching exercises. On days when the exercise was accompanied with a muscle biopsy, the exercise was performed prior to the biopsy and 
always after a morning fast. However, at days when only the exercise protocol was performed, there was no dietary control.

The eccentric exercise was performed using a custom-built computer-controlled dynamometer (Multicont-II, Mediagnost, Budapest and Mechatronic Kft, Szeged, Hungary) calibrated each exercise day according to the instructions provided by the manufacturer. In order to increase the available range of motion without affecting the stability of the knee joint, subjects exercised while lying in the prone position (Fig. 1).

The axis of rotation of the dynamometer was visually aligned with the axis of rotation of the knee (lateral femoral condyle). Fixing straps were placed on the ankle cuffs, thighs, and hips, to avoid unwanted forward sliding of the body during contraction. The functional range of motion $\left(120^{\circ}\right)$ was set electronically. The anatomical zero (full extension) of the knee equaled $130^{\circ}$ for the dynamometer (start position) while $10^{\circ}$ for the dynamometer equaled $120^{\circ}$ of the knee joint ankle (end position). The angular velocity was also set electronically to $120 \%$ and the lever arm was returned, after each eccentric contraction, to the starting point with $60 \%$ angular velocity (thus, allowing two seconds rest between each contraction). During this period subjects were instructed to relax and prepare for the following contraction. To initiate the lever arm of the dynamometer for each contraction, the subjects had to exert $20 \mathrm{Nm}$ torque. Throughout the exercise subjects were verbally encouraged to resist the rotating lever arm with maximum effort.

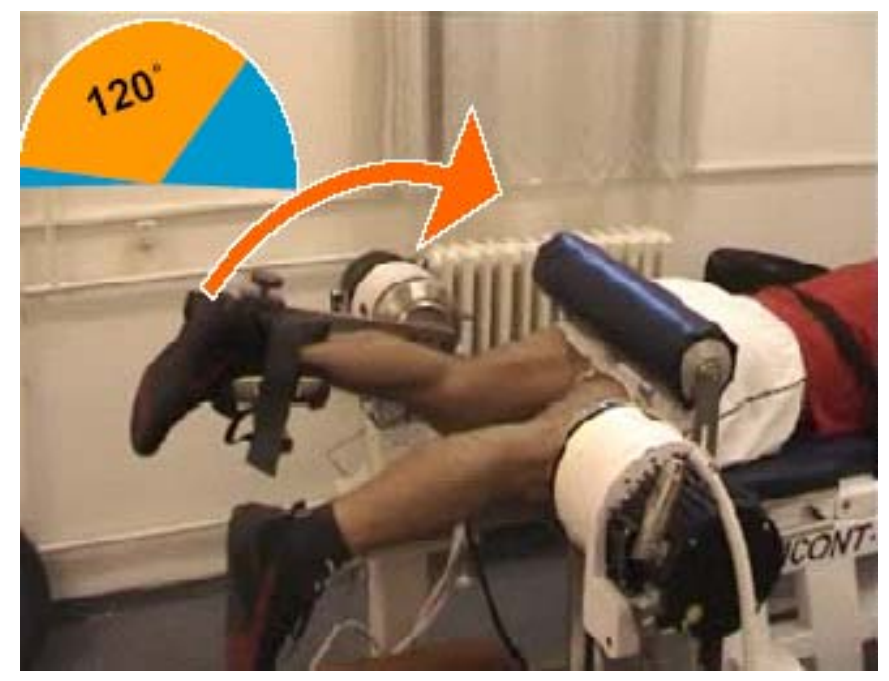

Figure 1. Eccentric exercise which consisted of six sets of 15 single leg MVC, using their non-dominant knee extensors. 
(ii)Calculation of Maximum average-torque (MAT): Each training day consisted of six sets of 15 repetitions. Maximum torque was collected for each repetition and the average of each set was calculated. MAT represents the average of the six sets.

(iii) Delayed Onset Muscle Soreness (DOMS): DOMS was measured using a $10 \mathrm{~cm}$ perceived analogue scale. The subjects were instructed that the left-end of the scale represents no pain while the right-end represents extreme pain. Thereafter all subjects were instructed to make a mark along the line according to their perceived pain upon palpation of their quadriceps muscle. The first measurement was taken $8 \mathrm{~h}$ after the first exercise session and thereafter measurements were taken $24 \mathrm{~h}$ after that point.

\subsubsection{Instruments and procedures for collecting muscle biopsies and the experimental design}

(i) Skeletal muscle biopsies: were taken from the middle portion of the vastus lateralis (non-dominant exercised leg) muscle under local anesthesia (1\% Lidocaine) by percutaneous needle biopsy using a 5-mm Bergström biopsy needle (Fig. 2). Muscle samples were quickly cleaned of any visible connective and adipose tissue and snapfrozen in liquid nitrogen $\left(\mathrm{N}_{2}\right)$. Samples were stored at $-80^{\circ} \mathrm{C}$ until analysis. All biopsies were collected after a morning fast and always between 8:00 and 9:00 am.
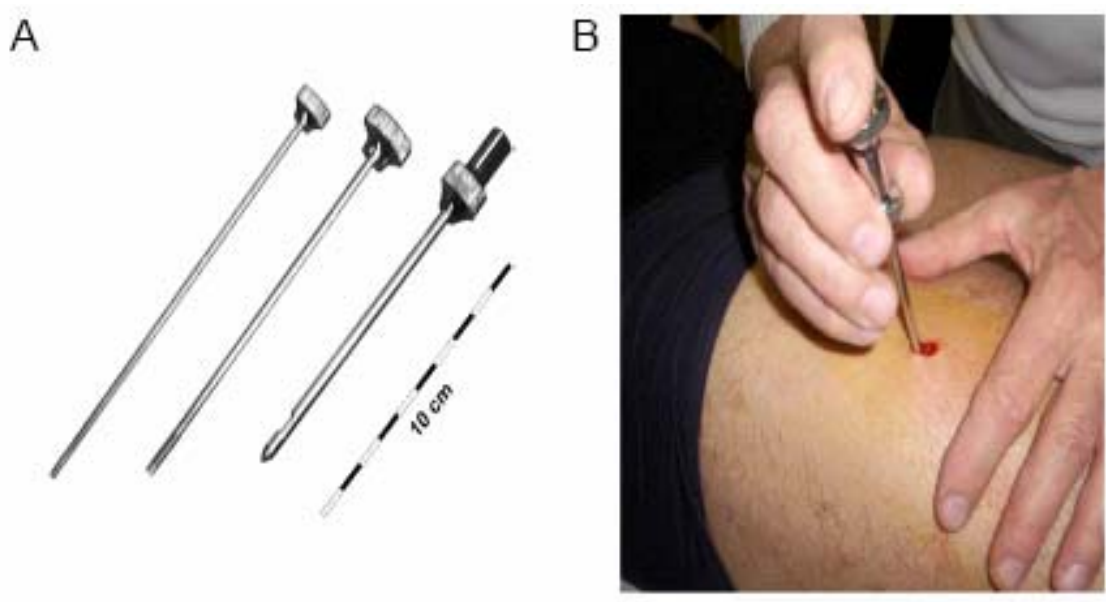

Figure 2. Bergström biopsy needle (A) and the penetration of it during muscle biopsy (B). 
(ii) Experimental design: Muscle biopsies and blood samples (drawn from the antecubital vein) were taken as indicated in Figure 3. Pre-exercise muscle biopsies and blood samples were taken from all subjects one week before starting the exercise protocol. At day 1, subjects had their first exercise bout that was then performed for six consecutive days. At day 3 after completing the third-day exercise, blood and biopsy samples again were collected. The final biopsies and blood samples were taken at day 7 . The same timeline protocol was followed by the control subjects, with the exception of the resistance exercise.

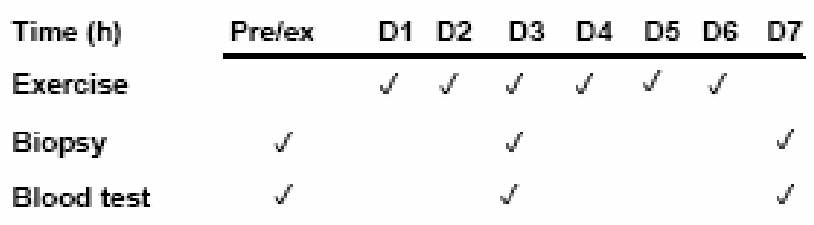

Figure 3. Experimental design for the experimental group. Note that the same timeline protocol was followed by the control subjects, with the exception of the resistance exercise. The Pre/ex time point corresponds to one week prior starting the exercise protocol. Abbreviation: (D1) to (D7) represent day 1 to day 7.

\subsubsection{Instruments and procedures for collecting $m R N A$ expression data}

(i)RNA isolation: Using Tri Reagent (T9424 Sigma Aldrich), RNA was isolated from each sample according to the manufacture's protocol. Briefly, each tissue was homogenized in $1 \mathrm{ml}$ Tri-reagent (Heidolf homogenizer) and the homogenate was centrifuged at $12,000 \mathrm{~g}$ for ten minutes at $4 \mathrm{C}^{\circ}$ (note that this was an additional centrifugation in order to remove insoluble material from the homogenate, as by its nature, muscle tissue is rich in extracellular membranes). Thereafter, the clear supernatant was stored for five minutes at room temperature to permit complete dissociation of nucleoprotein complexes. Next, each homogenate was supplemented with $0.2 \mathrm{ml}$ chloroform and the resulting mixture was stored at room temperature for 15 minutes. The mixture was then centrifuged at $12,000 \mathrm{~g}$ for fifteen minutes at $4 \mathrm{C}$ for phase separation. The aqueous phase, which contains exclusively the RNA, was then transferred to a fresh tube and precipitated by mixing with $0.5 \mathrm{ml}$ of isopropanol. Samples were stored at room 
temperature for ten minutes and then centrifuged at 12,000 $\mathrm{g}$ for another ten minutes at 4 $\mathrm{C}^{\circ}$. After precipitation, the supernatant was removed and RNA pellets were washed with $75 \%$ ethanol. Samples were then centrifuged at 7,500 $\mathrm{g}$ for five minutes at $4 \mathrm{C}^{\circ}$, ethanol was discarded, and RNA pellets were briefly air-dried for ten minutes. Finally, by adding $20 \mu \mathrm{l}$ distilled water, the RNA pellets were solubilized at $64 \mathrm{C}^{\circ}$ for two to three minutes. $1 \mu 1$ RNA was measured from each sample at 260/280 absorbance ratio (NanoDrop ${ }^{\circledR}$ ND1000 Spectrophotometer) to determine RNA concentration and purity. RNA was stored at $-80 \mathrm{C}^{\circ}$.

(ii)Reverse transcription reaction-cDNA synthesis: Two micrograms of RNA from each sample were reverse transcribed in a total volume of $40 \mu 1$. Reverse transcription reaction mixture [ $4 \mu 1$ of $10 \mathrm{X}$ reverse transcription buffer, $8 \mu \mathrm{l}$ of $\mathrm{MgCL}_{2}, 4 \mu \mathrm{l}$ of dNTP, $2 \mu \mathrm{l}$ of random primers, $1 \mu \mathrm{l}$ of rRNasin, $1 \mu \mathrm{l}$ of MuLV reverse transcriptase] was incubated at $45 \mathrm{C}^{\circ}$ for 50 minutes, heated at $90 \mathrm{C}^{\circ}$ for ten minutes in order to stop the reaction, and then quick-chilled at $-80 \mathrm{C}^{\circ}$ for ten to twenty minutes. cDNA samples were stored at $-20 \mathrm{C}^{\circ}$ for subsequent RT-PCR analysis.

(iii) Real time quantitative RT-PCR: The ABI Prism 7000 Sequence Detection System (Applied Biosystems) was used to quantify mRNA transcription for each gene. The real time RT-PCR reaction mixture consisted of $2 \mu \mathrm{l}$ of cDNA, $1.3 \mu \mathrm{l}$ primer, $12.5 \mu \mathrm{l}$ of TaqMan universal PCR master mix, and $9.2 \mu 1$ RNase-free water for a total volume of $25 \mu 1$. The amplification profile involved an initial step at $50{ }^{\circ} \mathrm{C}$ for two minutes, a second step at $95{ }^{\circ} \mathrm{C}$ for ten minutes, and was then followed by 40 cycles at $95{ }^{\circ} \mathrm{C}$ for 15 seconds and at $60{ }^{\circ} \mathrm{C}$ for one minute. All reactions were set up in duplicate and repeated once.

Analyses of the real-time quantitative PCR data were performed using the comparative threshold cycle [Ct] method as suggested by Applied Biosystems (User Bulletin \#2). Ct values are defined as the PCR amplification cycle in which the reporter signal is greater than the minimal detection level, and $\mathrm{Ct}$ is inversely related to the relative abundance of a particular transcript. During PCR, the template DNA quantity doubles at each cycle. Therefore, the target quantity $X_{\text {target }}$ at threshold cycle $C t$ is given by: $X_{\text {target }}=2^{-\triangle C T}$. 
The relative expression of different mRNAs was determined by relative quantification $\Delta C \mathrm{~T}=C_{\mathrm{T}}$ target $-C_{\mathrm{T}} \beta$-actin, where $\beta$-actin represents the reference housekeeping gene.

It should be mentioned that $\beta$-actin was selected, as an internal standard housekeeping gene, based on recent evidence that showed $\beta$-actin to be the most stable expressed housekeeping gene following high intensity eccentric exercise (Mahoney et al., 2004).

Pairs of primers and TaqMan probes were designed by Applied Biosystems (inventoried TaqMan ${ }^{\circledR}$ gene expression assays). All assays were purchased from Applied Biosystems and assay IDs are given in parenthesis below:

(MyoD1 (Hs00159528_m1); Myogenin (Hs00231167_m1); Myf5 (Hs00271574_m1); GDF8 (Hs00193363_m1); p21 (Hs00355782_m1); Ki67 (Hs00267195_m1); $\beta$-actin (Hs00242273_m1)).

\subsubsection{Instruments and procedures for collecting Creatine kinase (CK), lactate dehydrogenase (LDH) data}

Approximately $10 \mathrm{ml}$ of blood were drawn from the antecubital vein and analyzed by a Hitachi 902 clinical chemistry analyzer. CK and LDH kits were purchased from Diagnosticum Zrt and Dialab Kft (Budapest, Hungary), respectively.

\subsubsection{Instruments and procedures for morphological data collection}

Histology and Immunohistochemistry: All samples were fixed in 7\% buffered formalin and processed by standard techniques to paraffin wax. For tissue processing, enclosed automatic processor (PathCenter, Shandon) was used according to routine histopathological processing. From paraffin embedded blocks $4 \mu \mathrm{m}$ sections were cut and laid on silanized (APES, 3-aminopropyltriethoxysilane) slides. In addition to standard haematoxylin- and eosin-stained sections, immunohistochemical staining was performed using fixed, paraffin-embedded tissue sections and antibodies specific for fibronectin (polyclonal, rabbit anti-human, DakoCytomation, A 0245) and desmin (monoclonal, mouse anti-human, clone D33, DakoCytomation, M 0760) antigens. Heat induced epitope retrieval was used for demasking epitopes. Citrate buffer at $\mathrm{pH} 6$ at $95^{\circ} \mathrm{C}$ for 35 minutes 
was applied. Incubation time with primary antibodies was 60 minutes at $25^{\circ} \mathrm{C}$. Dilutions for antibodies with $1 \%$ bovine serum albumin were: desmin 1:50, fibronectin 1:400. For detection and visualisation LSAB Duet kit and Diaminobenzidine were used. Sections for all biopsies were observed using a Nikon Eclipse, E600, microscope and the chosen sections were photographed with spot camera (Pixera Penguin 600CL Model). All sections were seen blind to the experimental treatment (exercise or control) by three different parties, one of which was independent to the study.

\subsection{Treatment of Data}

Statistical analysis: Mean and SD were calculated for each variable. Normality tests, Shapiro-Wilk's W test, were performed for all dependant variables. All variables, with the exception of MAT, were analyzed by Friedman ANOVA (a non parametric test alternative to repeated measures of ANOVA), since the variables of interest were not normally distributed, followed by the Wilcoxon Matched Pairs Test as a post hoc test, when appropriate. MAT was analyzed with repeated measures of ANOVA, following by a Scheffe test. In all dependent variables time was used as the repeated measures factor with three levels (pre/ex, day 3 and day 7) with the exception of MAT and DOMS were the repeated measures factor, time, had 6 and 8 levels respectively. Dependent variables were: mRNA gene expression of MyoD, Myogenin, Myf5, P21, Ki-67 and Myostatin; CK and LDH activity; mean MAT; DOMS; muscle fibers morphology; muscle fibers fibronectin and desmin staining. Statistical significance was accepted at $\mathrm{P}<0.05$ for and all tests were performed using STATISTICA 7 software package. 


\section{CHAPTER IV}

\section{ANALYSIS OF RESULTS}

\subsection{Indirect Markers of Muscle Damage}

The indirect markers of muscle damage investigated by the present study included: Maximum Average Torque (MAT), serum creatine kinase (CK) and lactate dehydrogenase (LDH) activities, and Delayed Onset Muscle Soreness (DOMS). All indirect markers of muscle damage, with the exception of MAT, were analyzed by Friedman ANOVA by ranks (since the variables of interest were not normally distributed) followed by the Wilcoxon Matched Pairs Test as a post hoc test, when appropriate. MAT was analyzed with repeated measures of ANOVA, following by a Scheffe test.

MAT was significantly decreased $(\mathrm{P}<0.006)$ between day 2 and day 5 compared to the first training session. At day 6, MAT recovered significantly from day $3(\mathrm{P}=0.007)$ and was not significantly different from the first training value (Fig.5).

Serum CK and LDH activities were significantly increased throughout the study, although CK was significantly greater at day $7(\mathrm{P}=0.03)$ compared to the day 3 levels (Fig.6).DOMS peaked at day 3 and then gradually decreased such that at day 5 was significantly lower from day 3 (Fig.4). 


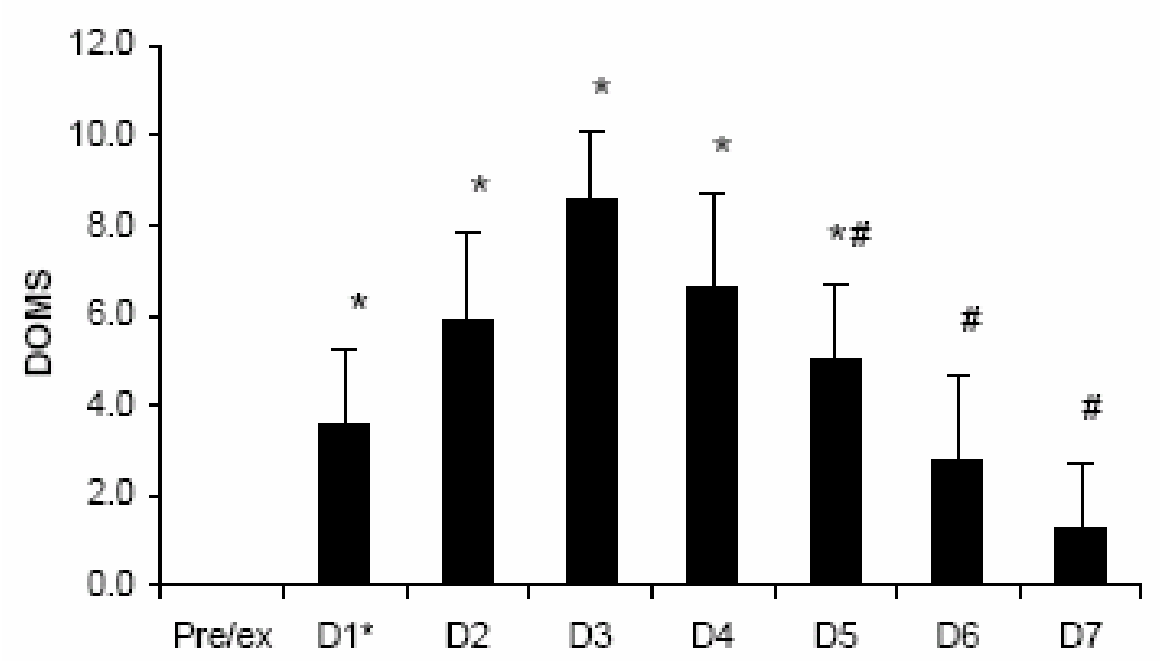

Figure 4. Delayed Onset Muscle Soreness (DOMS).DOMS peaked at day 3 and then gradually decreased such that at day 5 was significantly lower from day 3. Values are means \pm SD. ${ }^{*}$ significant difference $(\mathrm{P}<0.05)$ vs. pre exercise level, \# significant difference $(\mathrm{P}<0.05)$ vs. day 3. $\mathrm{D} 1 *$ : Measurement was taken $8 \mathrm{~h}$ after the first exercise session and thereafter measurements were taken $24 \mathrm{~h}$ after that point.

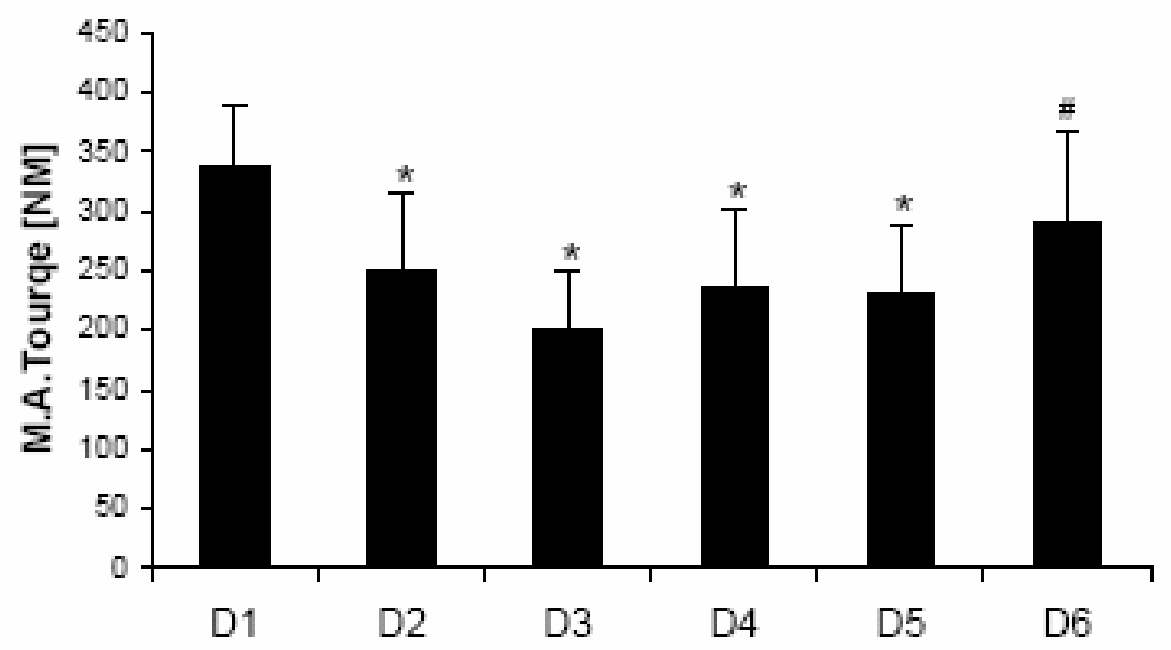

Figure 5. Maximum average-torque (MAT). Compared to the first training session, MAT was significantly decreased from day 2 to day 5. At day 6, MAT recovered significantly from day 3 and was not significantly different compared to the first training session. Values are means, $\mathrm{SD} .{ }^{*}$ significant difference $(\mathrm{P}<0.05)$ vs. day 1, \# significant difference $(\mathrm{P}<0.05)$ vs. day 3. Abbreviation: (D1) to (D6) represent the exercise days. 
a

$\square$ pre/ex. $⿴ 囗$ Day 3 Day 7

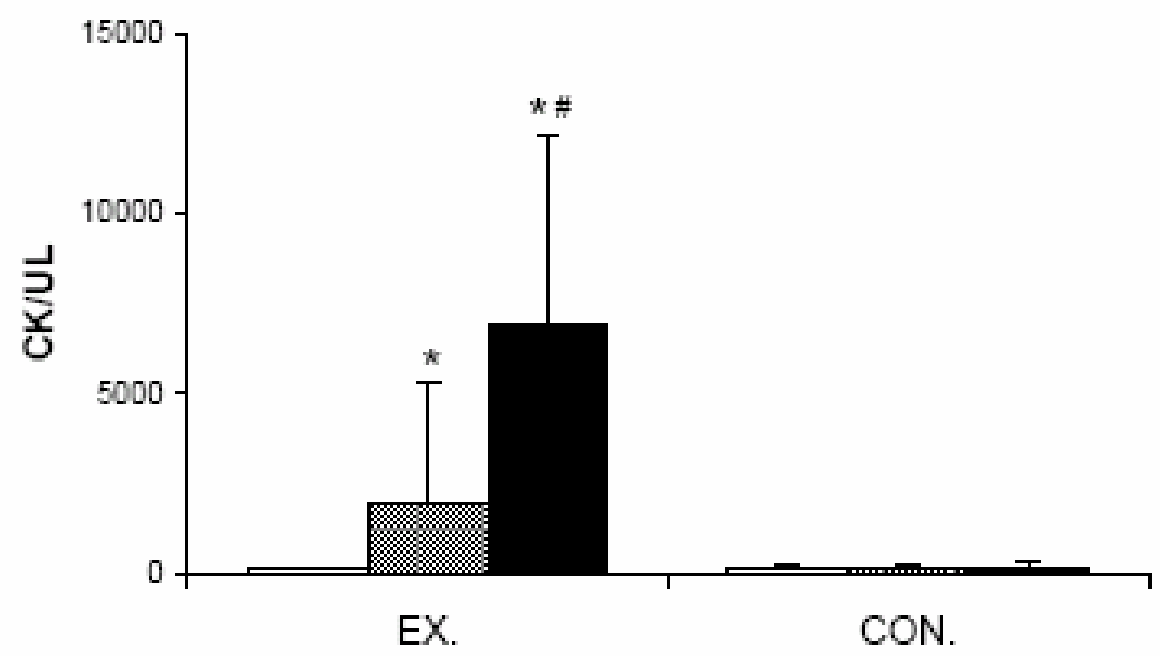

b
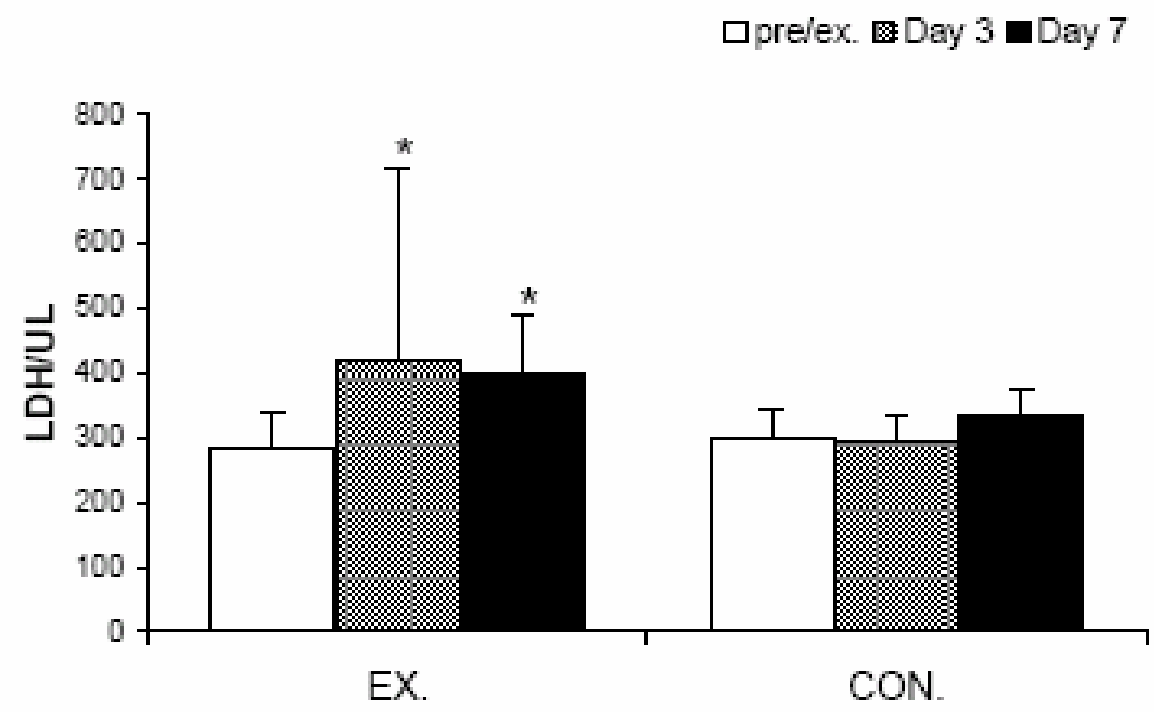

Figure 6. Creatine Kinase (CK) and Lactate Dehydrogenase (LDH) Activities. Serum CK (a) and LDH activity (b) were significantly increased throughout the study. CK, though, at day 7 was significantly increased over the day 3 levels. Values are means, SD. * significant difference $(\mathrm{P}<0.05)$ vs. pre exercise level, \# significant difference $(\mathrm{P}<0.05)$ vs. day 3 . 


\subsection{Direct Markers of Muscle Damage}

Muscle Histology: All muscle biopsies taken at pre-exercise (Fig.7A), at day 3 (Fig.7B) and at day 7 (Fig.7C) after three and six consecutive bout of eccentric exercise respectively, showed normal fiber appearance with well-ordered fascicles and tightly packed fibers. In both groups, experimental and control, there was no evidence of gross myofiber lesions. All fibers seen in cross-sections had polygonal appearance with no observable evidence of enlarged and/or rounded fibers (Figs 7 and 8). In some cases rounded fibers were observed at the periphery of the muscle biopsy. However, at no instance rounded fibers were observed in the centre of the biopsy. Due to the fact that such fibers were observed in both groups and at all times, the presence of those fibers can only be attributed to the biopsy procedure and not to the exercise. In addition, at no instance those or others fibers were accompanied with mononuclear cells infiltration. There was no evidence of myofiber degeneration and/or necrosis. Only one subject showed evidence of gross myofiber disturbances with infiltration of mononuclear cells, myofiber degeneration and necrosis, all of which commenced at day 7 (Fig.9). This subject was the one that displayed extremely high CK activity.

Fibronectin and Desmin staining: Plasma fibronectin at no instance was observed within the muscle fibers (Fig. $7 D, E$ and F) with the exception of the subject that showed gross myofiber degeneration and necrosis. In this subject, at day 7 , the majority of muscle

fiber seen in cross and longitudinal sections contained staining of plasma fibronectin (Fig.9B).

Alike with fibronectin, no observable loss of desmin staining was seen in any of the subjects with the exception of the same subject that showed, at day 7 , increased fibronectin staining within the majority of muscle fibers. In this subject, at day 7, most of the fibers also lacked desmin staining (Fig.9C). 


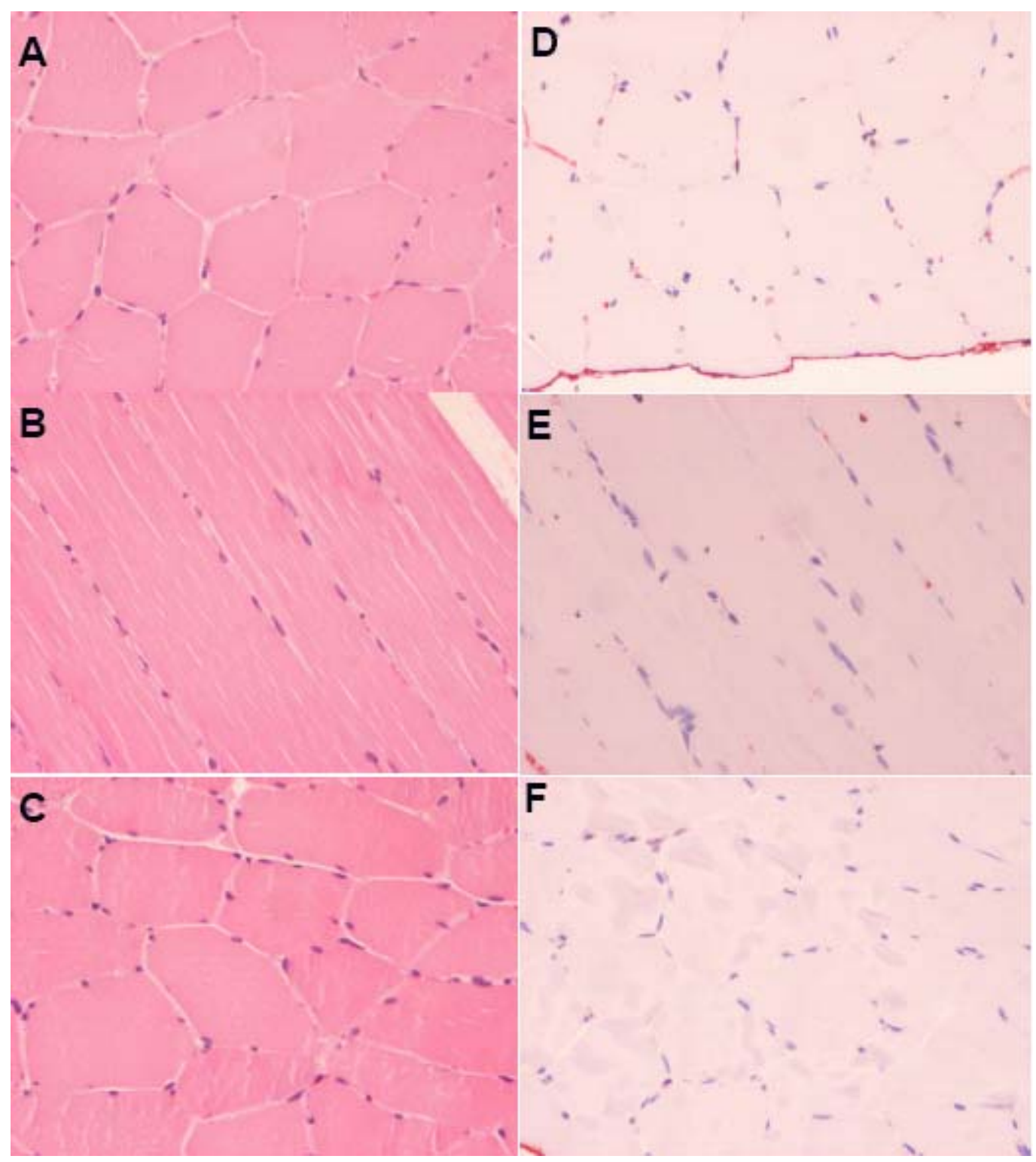

Figure 7. Muscle biopsy sections taken from the exercise group. Left panel (A, B, and C) shows sections taken from a Vastus Lateralis muscle biopsy and stained with hematoxylin-eosin. Right panel (D, E, and F) shows sections taken from a Vastus Lateralis muscle biopsy and stained with anti-human plasma fibronectin. Note that $\mathrm{B}$ and $\mathrm{E}$ are longitudinal sections while $\mathrm{A}, \mathrm{D}, \mathrm{C}$ and $\mathrm{F}$ are cross sections. All sections are from the exercise group taken at pre/exercise level (A, D), at day 3 $(\mathrm{B}, \mathrm{E})$, and at day $7(\mathrm{C}, \mathrm{F})$. No enlarged or rounded fibers and no evidence for mononuclear cell infiltration are seen in B and C. No fibronectin staining within the muscle fibers is seen in E and F. Magnification X 200 in all pictures. 


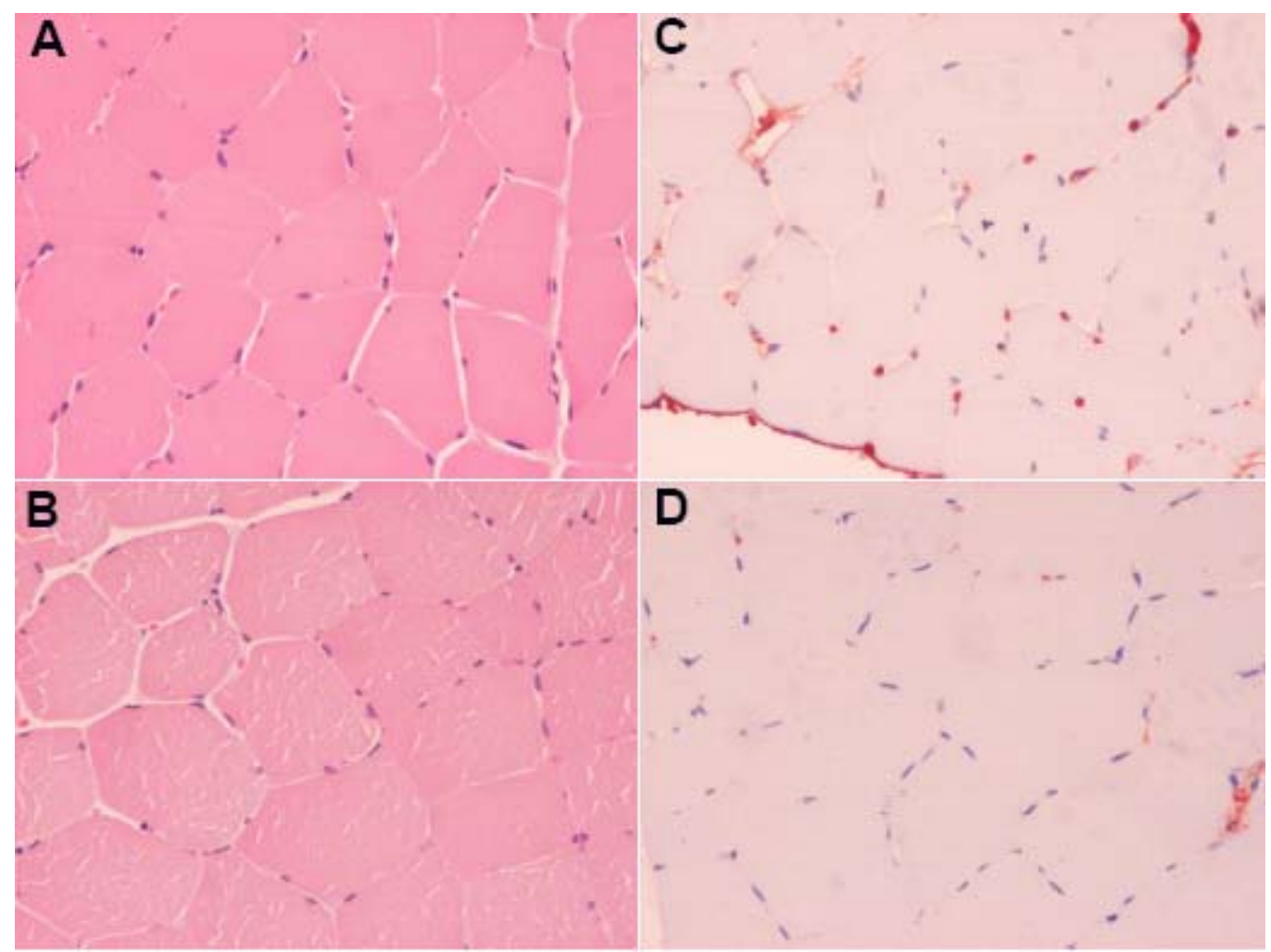

Figure 8. Muscle biopsy sections taken from the control group. Left panel (A and B) shows cross sections taken from a Vastus Lateralis muscle biopsy and stained with hematoxylin-eosin. Right panel (C and D) shows cross sections taken from a Vastus Lateralis muscle biopsy and stained with anti-human plasma fibronectin. All sections are from the control group taken at day $3(\mathrm{~A}, \mathrm{C})$ and at day $7(\mathrm{~B}, \mathrm{D})$. No enlarged or rounded fibers and no evidence for mononuclear cell infiltration are seen in A and B. No fibronectin staining within the muscle fibers is seen in $\mathrm{C}$ and D. Magnification X 200 in all pictures. 


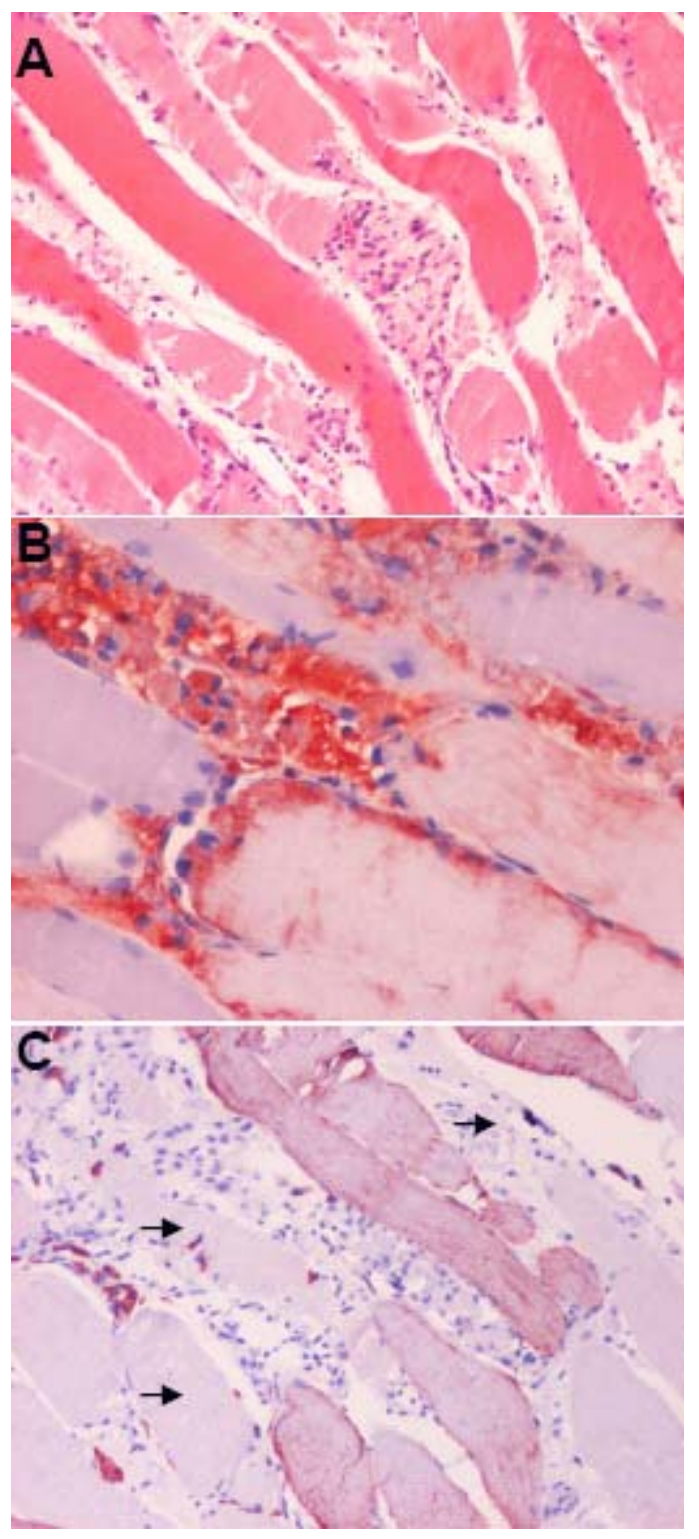

$\underline{\text { Figure 9. }}$. Muscle biopsy sections with direct evidence of muscle damage. Muscle biopsy longitudinal sections from the only subject that showed direct indices of muscle damage at day 7. Sections are stained with hematoxylin-eosin (A), anti-human plasma fibronectin (B) and anti-desmin (C). Clear evidence for gross myofiber disturbances with infiltration of mononuclear cells and myofiber degeneration is seen in all sections. Fibronectin staining is observed within the degenerative fibers (B) and loss of desmin staining is seen in C. Loss of desmin staining is indicated in some fibers by arrows. Magnification X 100 in A, C and X 200 in B picture. 


\subsection{Myogenic regulatory factors (MRFs)}

The mRNA expression of MRFs (MyoD, Myogenin, and Myf5) were analyzed by Friedman ANOVA by ranks (since the variables of interest were not normally distributed) followed by the Wilcoxon Matched Pairs Test as a post hoc test, when appropriate. The mRNA expression for MyoD decreased significantly by $45 \%(\mathrm{P}=0.03)$ at day 3 after three bouts of EE (Fig.10a), while myogenin mRNA (Fig.10b) increased significantly by 1.9 fold $(\mathrm{P}=0.02)$, compared to the pre/exercise values. The mRNA expression for Myf5 was not significantly changed at any time (Fig.10c). The mRNA expression for all MRFs had returned to the pre/ex levels by day 7 . 


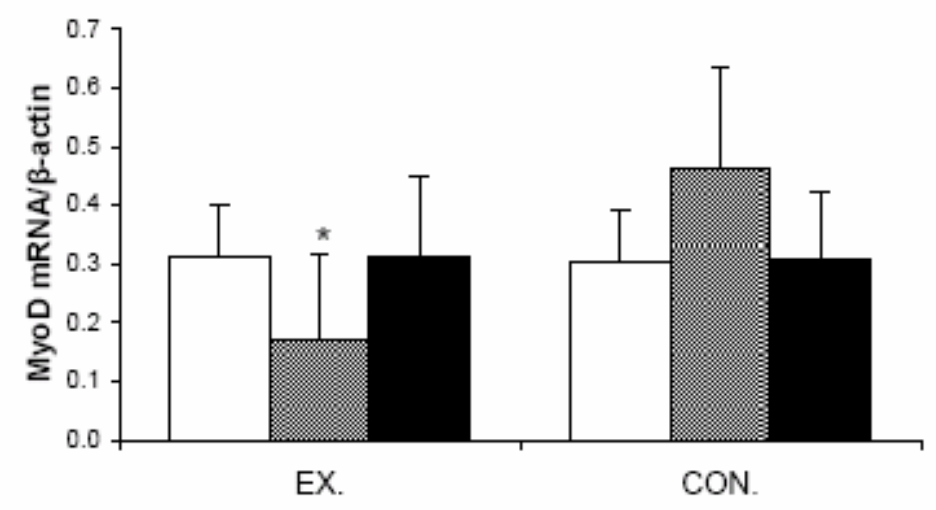

b

口Pre/ex. 圆 Day 3 Day 7

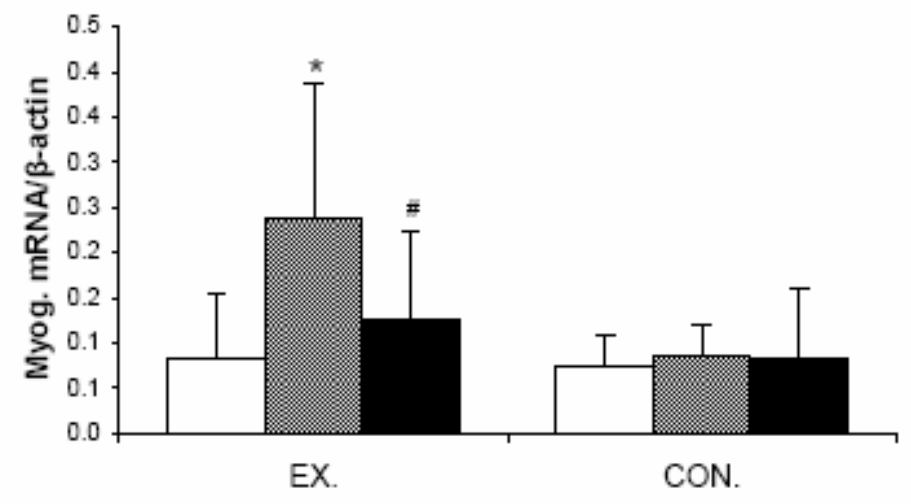

C

口Pre/ex. 욤 $48 \mathrm{~h}$-144h

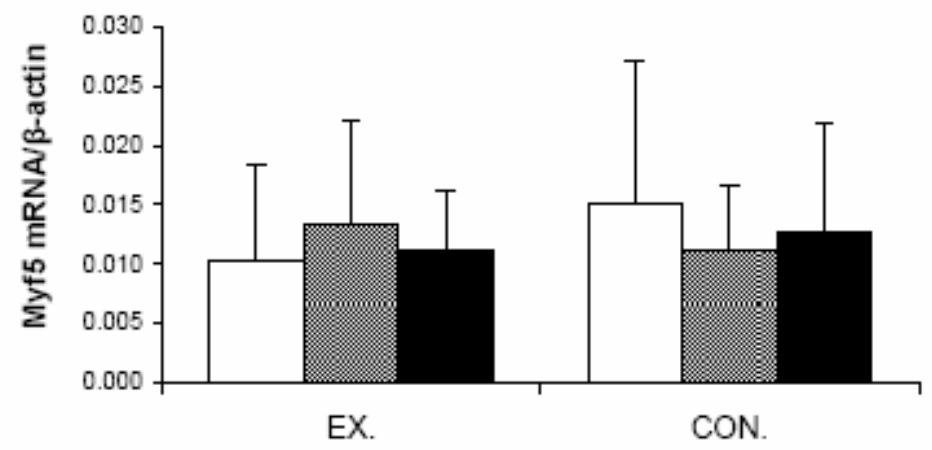

Figure 10. Relative RT-PCR results for MyoD (a), myogenin (b) and myf5 (c) mRNA expression using $\beta$-actin as an internal standard. In the exercise group at day 3 , MyoD mRNA (a) decreased significantly $(-45.2 \%, \mathrm{P}=0.03)$ while the mRNA for 
myogenin (b) increased significantly ( 1.9 fold, $\mathrm{P}=0.02$ ). The mRNA expression for myf5 (c) was not significantly changed at any time. No significant changes were observed in the control group at any time. Values are means, SD. * significant difference $(\mathrm{P}<0.05)$ vs. pre-exercise level, \# significant difference $(\mathrm{P}<0.05)$ vs. day 3. Abbreviation: $(\mathrm{EX})$ and $(\mathrm{CON})$ represent exercise and control groups respectively.

\subsection{Markers of proliferation and differentiation}

The mRNA expression of p21 and Ki-67 was analyzed by Friedman ANOVA by ranks (since the variables of interest were not normally distributed) followed by the Wilcoxon Matched Pairs Test as a post hoc test, when appropriate. The mRNA expression for Ki-67 gene, a marker of active cell proliferation, increased significantly by day 3 (2.4 fold, $\mathrm{P}=0.01$ ) and by day 7 had significantly increased further (12.1 fold, $\mathrm{P}=0.007$ ) (Fig.11b). On the other hand the mRNA expression for $\mathrm{p} 21$ and myogenin, markers of cell differentiation, increased significantly only at day 3 by $4.1(\mathrm{P}=0.007)$ and 1.9 fold, respectively (Figs.11a, 10b). At day 7, after six consecutive days of EE, both had returned to the pre/ex levels. 


\section{a}

口Pre/ex. 圆Day 3 由 Day 7

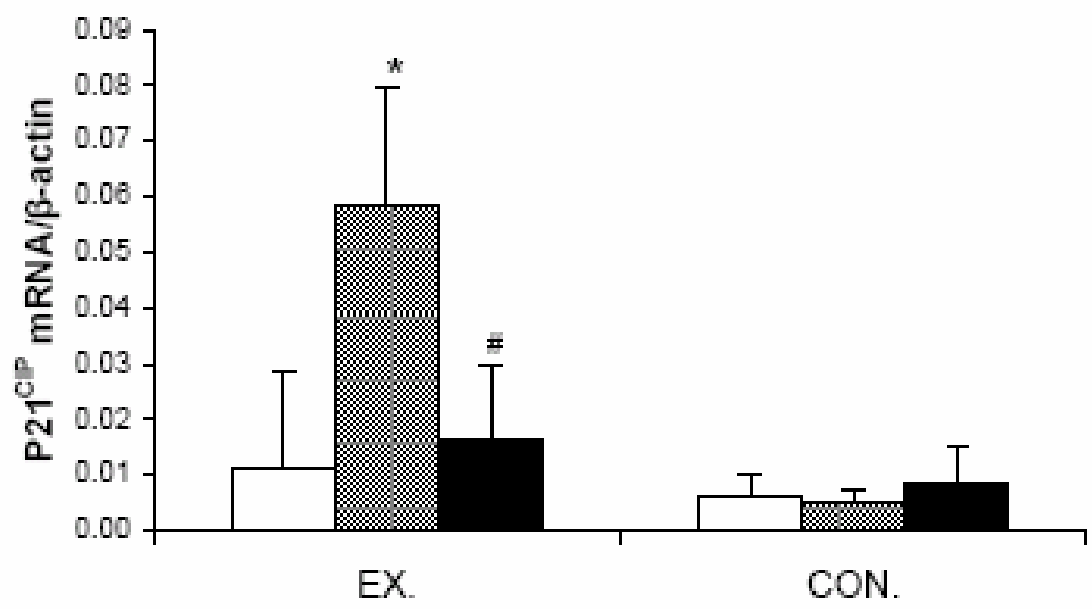

b

口Pre/ex. 읍 Day 3 Day 7

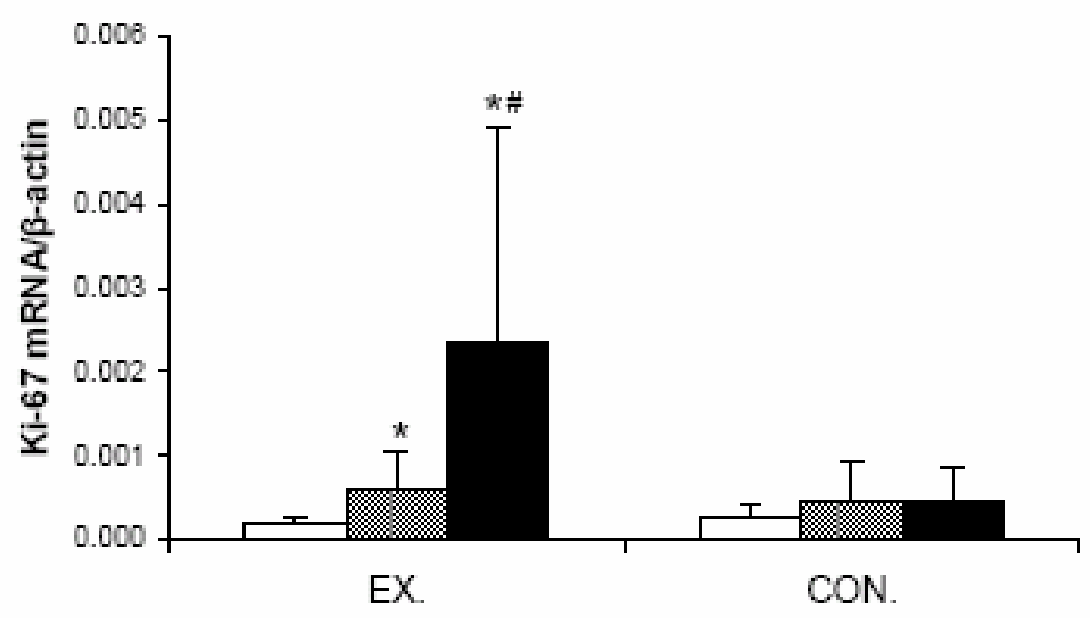

Figure 11. Relative RT-PCR results for P21 (a) and ki-67 (b) mRNA expression using $\beta$ actin as an internal standard. In the exercise group at day 3, P21 (a) and ki-67 (b) mRNA increased significantly, 4.1 fold, $\mathrm{P}=0.007$ and 2.4 fold, $\mathrm{P}=0.01$ respectively. At day 7 the mRNA for p21 was not significantly different compared to the pre exercise level, while ki-67 mRNA increased further $(12.1$ folds, $\mathrm{P}=0.007)$. No significant changes were observed in the control group at any time. Values are means, SD. * significant difference $(\mathrm{P}<0.05)$ vs. pre-exercise level, \# significant difference $(\mathrm{P}<0.05)$ vs. day 3. Abbreviation: (EX.) and $(\mathrm{CON}$.) represent exercise and control groups respectively. 


\subsection{Myostatin}

The mRNA expression for myostatin, a negative regulator of skeletal muscle growth and regeneration, decreased significantly by $74 \%(\mathrm{P}=0.007)$ at day 3 and by $72 \%$ $(\mathrm{P}=0.01)$ at day 7 (Fig. 12).

口Pr/ex. ‥ Day 3 Day 7

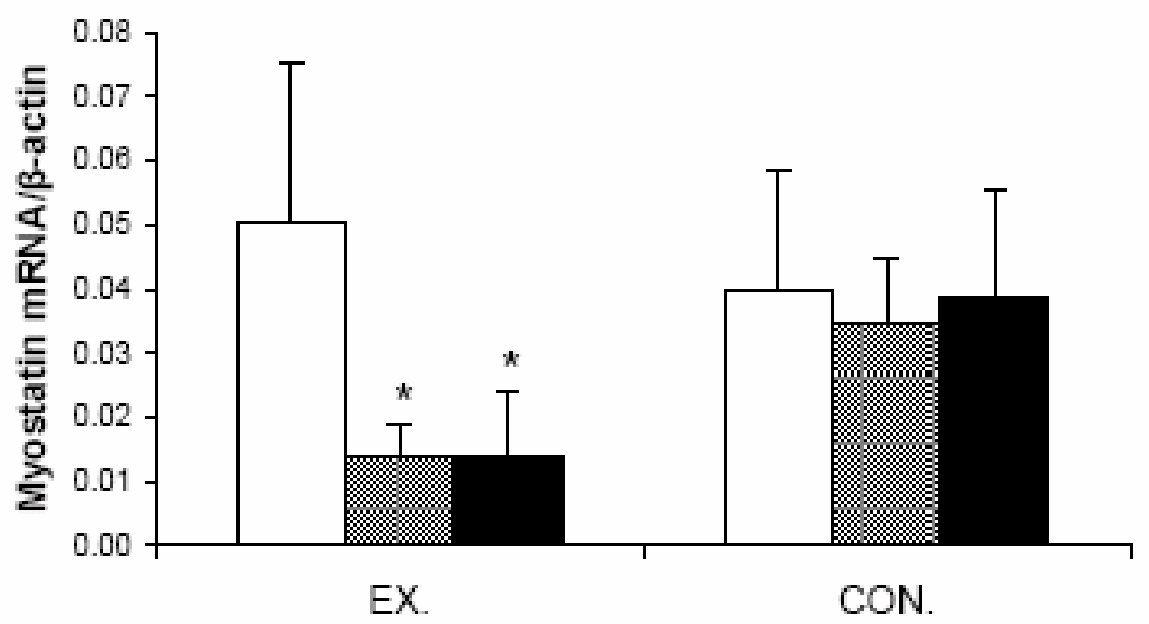

Figure 12. Relative RT-PCR results for myostatin mRNA expression using $\beta$-actin as an internal standard. In the exercise group, myostatin decreased significantly $(-74 \%$, $\mathrm{P}=0.007)$ at day 3 and day $7(-72 \%, \mathrm{P}=0.01)$. No significant changes were observed in the control group at any time. Values are means, SD. * significant difference $(\mathrm{P}<0.05)$ vs. pre-exercise level. Abbreviation: (EX.) and $(\mathrm{CON}$.) represent exercise and control groups, respectively. 


\section{CHAPTER V}

\section{INTERPRETATION OF THE RESULTS}

The purpose of the present study was to investigate the effects of repeated bouts of eccentric exercise for six consecutive days. This was done in an attempt to determine the appropriateness of exercise continuation with damaged muscles. In order to accomplish this, we have examined direct and indirect markers of muscle damage as well as the expression of key myogenic genes. The results presented here indicate that, repeated bouts of eccentric exercise for six consecutive days do not cause gross myofiber but may impair the adaptation process, since the expression of MRFs was attenuated.

\subsection{Muscle damage, Direct and Indirect markers.}

In the present study at day 3 after three consecutive days of strenuous eccentric exercise $\mathrm{CK}$ and $\mathrm{LDH}$ activities were significantly increased. The continuation of exercise for three additional days prolonged the increased activity of LDH while CK activity was increased even further compared to day 3. By the end of the present study, CK and LDH activities were still significantly elevated compared to the pre exercise levels and only torque had recovered. Chen and Hsieh (2001) following a similar protocol as in the present study reported that $\mathrm{CK}$ and $\mathrm{LDH}$ activities had returned to the pre exercise levels by the end of their study. In addition they also observed that torque deficit, as well as the $\mathrm{CK}$ and $\mathrm{LDH}$ activities in the repeated EE bout group, were similar to those observed for a single EE bout. They concluded that repeated bouts of EE did not exacerbate muscle damage indices, but in contrast, the extent of muscle damage is identical to that seen with the single bout of EE. It should be noted that despite the similarity in exercise intensity (MVC), the present study utilized three times higher exercise volume than did Chen and Hsieh (90 vs. 30 eccentric contractions/day).

In the study of Chen and Hsieh (2001) mentioned above, although torque deficit was identical to that seen following the single bout of EE, torque in both groups was not completely restored by the end of the study ( 7 days after the first EE) and was 
significantly lower compared to the pre-exercise levels. In contrast, the present study showed that torque recovery was not affected by the repeated bouts of EE so that by day 6 , there was no significant difference as compared to the pre-exercise levels. Similar findings to Chen and Hsieh (2001) were reported from Nosaka and Newton (2002) and also from Chen (2003). All the aforementioned studies observed a constant recovery of torque following the initial bout of EE, however, in all three cases and by the end of each study, torque was significantly lower as compared to the pre-exercise levels, in either group (single or repeated). At first glance, it seems strange because the present study have used a more strenuous exercise protocol than the other three studies, did. Particularly, with the exception of Nosaka and Newton (2002) that utilized the $50 \%$ of the MIF, Chen and Hsieh (2001), Chen (2003) and the present study have all utilized MVC while the current study utilized higher exercise volume than the abovementioned studies (90 vs. 30 Chen and Hsieh (2001); 90 vs. 30 Nosaka and Newton (2002); 90 vs. 30 or 70 Chen (2003). Given the above mentioned data one would expect to observe greater impairment of torque recovery in the present study rather than to see the greater recovery as compared to the other studies. It should be emphasized however that the EE in the present study was carried out using the knee extensors while all the other three studies have used the elbow flexors. Based on the results of Jamurtas et al. (2005) that reported larger torque decreases in elbow flexors than the knee extensors, it appears that this fact could be the reason for differences reported above. In addition, the torque data reported by the present study were taken during the exercise while in all the other studies torque data are based on MIF measured in times other than during the exercise.

In contrast to torque recovery that was not affected by the repeated bouts of $\mathrm{EE}$ in the present study, CK and LDH activities were significantly increased at all times measured while $\mathrm{CK}$ was increased even further compared to day 3. In the abovementioned studies of Chen and Hsieh (2001); and Chen (2003), CK was found to be significantly higher compared to the pre-exercise levels up to day 6 whereas at day 7 both studies reported that $\mathrm{CK}$ was not significantly different from the pre-exercise levels. Based on Jamurtas et al. (2005) findings that reported greater enzyme (CK, LDH, Mb) activity in elbow flexors as compared to knee extensors, one would have expected the present study to find lower CK and LDH levels compared to the studies of Chen and 
Hsieh (2001); and Chen (2003). It is important to note here, however, that in the study of Jamurtas et al. (2005) the exercise intensity was at $75 \%$ of predetermined eccentric peak torque. A possible scenario to explain the greater enzyme releases in Elbow flexors as compared to knee extensors maybe the everyday life activities. Particularly, knee extensors are subjected to a greater amount of eccentric contractions during daily activities such as walking, climbing down stairs etc. Under these conditions knee extensors are more preconditioned to eccentric contractions than elbow flexors and based on the repeated bout effect it is not unreasonable to observe these differences especially with an exercise intensity of $75 \%$ of predetermined eccentric peak torque used by Jamurtas et al. (2005). It may be that when the exercise is repeated and its intensity is MVC, the preconditioning of knee extensors, from the daily activities, may not be enough to avoid greater enzyme release. Having in mind that knee extensors are far bigger muscles than elbow flexors, the quantity of enzyme release therefore may not be unreasonable to be higher, a fact that can account for the differences observed between the present study and those of Chen and Hsieh (2001); and Chen (2003). The lack of a single EE bout group in the present study does not allow for the conclusion that muscle damage was exacerbated, because the possibility cannot be excluded that a single EE bout of the present exercise protocol could have produced the same degree of enzyme release, as seen in the repeated-bout group. However, it seems that exercise volume is an important factor in determining the degree of enzyme release under repeated bouts of eccentric exercise, and this fact should be carefully considered.

Despite the increased activities of $\mathrm{CK}$ and $\mathrm{LDH}$ at all measurement times, fibronectin staining was never observed within the muscle fibers in eight of nine subjects (see results) indicating that there was no sarcolemma disruption. Fibronectin under normal circumstances is excluded from the muscle fibers and has been shown to be an excellent marker for sarcolemma damage (Crenshaw AG et al., 1993; Thornell LE et al., 1992). Consequently, influx of fibronectin within muscle fiber can reflect either loss of sarcolemma integrity or increase membrane permeability to a particular protein. The fact that fibronectin was never observed within muscle fiber suggests that sarcolemma was neither disrupted and neither became permeable for fibronectin. 
The results presented here support previous observations that report no sarcolemma damage after a single bout of 210 maximum voluntary eccentric contractions (Crameri RM et al., 2004), downstairs running, eccentric bicycling or downhill treadmill running (Yu JG et al., 2002). In the present study we suspected that the single-bout of EE used by the aforementioned studies was not sufficient to induce sarcolemma damage. However, in contrast to our hypothesis it appears that repeated bouts of EE cannot induce gross sarcolemma damage in humans either. The literature suggests that during repeated bouts of EE an adaptation effect may occur as early as $24 \mathrm{~h}$ after the initial bout by the help of which muscle may no longer be susceptible to further damage (Chen TC and Hsieh SS, 2001). Therefore, in the present study, it may be that after the first bout of EE muscle damage was attenuated due to the abovementioned rapid adaptation. Additionally, the fact that MAT was significantly decreased between day 2 and day 5 compared to the first training session, indicates that these bouts were performed with weakened leg so that the possibility of damage in those bouts was decreased. The aforementioned reasons may well interpret the lack of gross sarcolemma and/or myofiber damage despite the fact that EE was performed for six consecutive days.

In contrast to the latter logic, the increased activities of CK and LDH suggest that muscle damage in the present study was not attenuated but was instead exacerbated. That is, given the increased activities of CK and LDH one would have assumed that three repeated bouts of EE induced muscle damage, while the continuation of exercise for three additional days exacerbated muscle damage. The present study, however, using routine histological staining showed no evidence of gross myofiber damage, no infiltration of inflammatory cells within the myofibers, no myofiber degeneration and/or necrosis, and no sarcolemma damage as stained by anti-fibronectin antibody.

In view of the latter paradox it is important to explore the reasons that may explain the increased activities of CK and LDH despite the lack of sarcolemma damage found by the present study. One reason could be the muscle biopsy itself because it allows collection of only a sliver of muscle and therefore may not be representative of the whole muscle because damaged tissue may be located in regions that are not biopsied.

Another determinant could be the site of the muscle biopsy. In humans, regions close to the myotendinous junction cannot be biopsied for safety reasons. Since the present 
study examined muscle biopsies taken from the mid-belly of Vastus Lateralis, any damage in other regions could not be quantified. This may well account for the increased activities of CK and LDH despite the lack of sarcolemma damage in the muscle midbelly.

Moreover, since the present study utilized light microscopy, any ultrastructural damage and/or alterations, showed to occur following EE, could not be quantified. For example, ultrastructural disturbances were observed by Hortobagyi T et al. (1998). In that study, two days following the first exercise bout (100 eccentric contractions with the quadriceps muscle), electron microscopy revealed substantial disorganization of the myofillaments, widening of Z-lines, and Z-line streaming whereas seven days later no abnormality was observed. The same disturbances were observed two days after a second exercise bout (two-weeks later) while no disturbances were observed seven days after the second exercise bout. In agreement, Friden et al (1983) also reported myofibrillar Z-band streaming, broadening and disruption, following a bout of eccentric bicycle for 30min. In that study, the disturbances were predominantly localized in type 2 fibers and were found in every third fiber up to 3 days after exercise and in one tenth of the fibers 6 days following the exercise.

Therefore, the possibility exists that ultrastructural damage might have occurred in the present study as well. The extent, however, of such ultrastructural damage, if any, was not sufficient to cause gross myofiber lesions, especially in the mid-belly of the muscle.

It is important to note here that the disturbances reported by Friden et al. 1983 were observed only in ultrastructural level because the overall fiber morphology as seen with light microscope was absolutely normal with no morphological fiber abnormality in any of the sections. In addition, Jones et al. 1086 reported that the first evidence of clear morphological fiber abnormality occurs well after the peak enzyme release. Particularly it was observed that muscle damage, with infiltration of inflammatory cells within the myofibers, was at its greatest when CK was almost returned to normal/pre-exercise levels. If this holds true, our results may be explained by the latter observation since CK and LDH activities were increased at all measurement times compared to pre-exercise level and CK at day 7 was increased even further compared to day 3. 
The reason for the delay between the peak enzyme leakage and the overt of muscle damage in structural level observed by Jones et al. 1986 remains unknown but it could be another determinant for observing no sarcolemma and/or muscle fiber damage in the present study.

\subsection{Myogenic regulatory factors}

In the present study we hypothesized that MRFs mRNA expression will increase as a result of repeated EE bouts. Our hypothesis was based on MRFs crucial role in determining the myogenic lineage and differentiation of myoblasts (Megeny L A and Rudnicky M A, 1995) together with their role in regulating gene transcription of several muscle genes (Li H and Capetanaki Y, 1993; Lin H et al., 1991; Wentworth B M et al., 1991).

At day 3, following three consecutive bouts of EE, we observed a significant upregulation for myogenin mRNA. Coincidently, with myogenin up-regulation, we also observed a significant MyoD mRNA down-regulation. Based on the crucial role of $\mathrm{MyoD}$ in myogenesis we were surprised to see $\mathrm{MyoD}$ down-regulation. Moreover, there was little effect of our protocol on MRFs mRNA expression, even at day 7. There are two possible reasons that could explain the lack of increase in MRFs mRNA expression: (i) it is possible that MRFs protein expression has been regulated by post transcriptional mechanisms, or (ii) MRFs mRNA expression occurred at times that were not tested in the present study. However if none of those possibilities is the case, the attenuated expression of MRFs observed by the present study is quite unexpected.

Resistance exercise has been shown to induce the expression of MRFs (Bickel C S et al., 2003; Bickel C S et al., 2005; Hameed M et al., 2003; Psilander N et al., 2003; Yang $\mathrm{Y}$ et al., 2005) and evidence also suggests that repeated bouts of resistance exercise stimulate greater responses (Haddad F and Adams G, 2002). Even though, in the present study we have utilized a training protocol that is both damage and mechanical stimulus, repeated for six consecutive days, the mRNA expression of MRFs was minimal throughout the experimental period. Consequently in contrast to our hypothesis repeated bouts of EE impaired and/or attenuated the expression of MRFs. 
The reason for the attenuated MRFs mRNA expression observed by the present study is unknown but it might be a consequence of the relatively short rest intervals (24h) between the exercise bouts. Indeed, Haddad and Adams (2002) reported that long rest intervals (48h) between two-repeated bouts of isometric exercise resulted in much greater myogenic responses compared to short ( 8 or $24 \mathrm{~h}$ ) rest intervals. Thus it is not unreasonable to believe that this could have been the reason for the attenuated MRFs expression observed by the present study.

\subsection{Myostatin}

In the present study, we also observed a dramatic Myostatin mRNA downregulation $(\sim 73 \%)$ at all measurement times. Myostatin acts mainly by inhibiting activation, proliferation and differentiation of satellite cells (Dominique J E and Gerard C, 2006; Joulia D et al., 2003; Langley B et al., 2002; McCroskery S et al., 2003). In light of the latter evidence, we reasoned that myostatin down-regulation would most probably complement increase activity of SCs. SCs, once activated start to express MRFs that are crucial in establishing the myogenic lineage (MyoD, Myf5) and terminal differentiation (myogenin, Myf6) of myoblasts (Megeny L A and Rudnicky M A, 1995). Consequently, we hypothesized that suppression of myostatin would be an additional reason to expect increased expression of MRFs. Even though the expression of myostatin was dramatically decreased we were unable to support our hypothesis because the expression of MRFs, with the exception of myogenin, was attenuated at all measurement times. In contrast to our observation, Shibata et al. (2006) reported different expression patterns between myostatin and MRFs during muscle regeneration in Japanese-cattle. In agreement with the present study, reductions in myostatin mRNA have been shown

previously following a single bout (-56\%) and 9-weeks (-34\%) of resistance training (Kim J et al., 2005; Roth S M et al., 2003). In contrast, increased myostatin mRNA and protein levels were reported following six and 12-weeks of resistance training (Willoughby D S, 2004). Peter et al. (2003) also observed increased myostatin mRNA expression $30 \mathrm{~min}$ after a single bout of 30 eccentric contractions in rat dorsiflexors. 
Myostatin is a negative regulator of skeletal muscle growth, and considering its role and function, the contradictory findings mentioned above are not surprising. According to "Chalones" hypothesis, organ size is regulated by specific negative regulators produced by a given tissue (Bullough W S, 1965). Myostatin could be such a chalone for muscle tissue, by which skeletal muscle regulates its growth and regeneration (McCroskery S et al., 2005). A stimulus such as resistance exercise might complement myostatin downregulation to enable skeletal muscle to achieve optimum repair and/or growth. Once optimum growth and/or repair have been achieved, skeletal muscle would most probably up-regulate myostatin expression in order to avoid excessive/unwanted muscle growth. Consequently, we suggest that, depending on the skeletal muscle status, resistance exercise induces "up or down-regulation" of myostatin and the net result of these actions will be optimum growth and/or repair.

\subsection{Cell Proliferation and Differentiation}

Under normal physiological conditions, skeletal muscle is an extremely stable tissue with little turnover of nuclei (1-2\% of myonuclei are replaced per week in rat) (Charge S B P and Rudnicki M A, 2004). Consequently, at steady state, indices of cell proliferation and/or differentiation within the muscle are few if not absent. It has been shown previously that a single bout of resistance exercise stimulates transient up-regulation of cell proliferation and differentiation indices (Bickel C S et al., 2005; Haddad F and Adams G, 2002). In rats, the imposition of a second bout (isometric-NEMS) has been observed to stimulate greater responses than those seen after a single bout (Haddad F and Adams G, 2002).

Our aim was to capture the general tendency of cell proliferation and differentiation in response to repeated bouts of exercise. Cell proliferation, and particularly satellite cell proliferation (myoblasts) assumes that quiescent cells, resting in G0, must be activated to re-enter the cell cycle. Ki-67 is an antigen that presents in the nuclei of proliferating human cells. Its expression occurs during the phase of the cell cycle designated as late G1, S, M, and G2. However during the G0 phase, the antigen cannot be detected and has 
been widely used as a putative proliferation marker, especially in relation to cancer (Endl E and Gerdes J, 2000; Scholzen T and Gerdes J, 2000). In the present study the mRNA for Ki-67 increased significantly after three consecutive eccentric bouts and increased even further after six bouts. This suggests two possibilities: cells within the cell cycle were preparing to enter the cell cycle $\mathrm{S}$ phase, since Ki-67 protein expression increases during S phase (Endl E et al., 1997; Scholzen T and Gerdes J, 2000) or/and the number of cells entering the cell cycle was increased. However, in both cases, lack of MRFs expression and the fact that we have analyzed whole muscle tissue, suggests that those cells represent a cell type other than skeletal muscle.

Myoblast differentiation assumes cell cycle arrest in the G0/G1 phase. The fact that cyclin-CDK inhibitor p21has been shown to promote cell cycle arrest in $\mathrm{G} 1$ and $\mathrm{G} 2 / \mathrm{M}$, together with the substantial role of myogenin during differentiation, simultaneous p21 and myogenin upregulation have been generally viewed as markers of myoblast differentiation.

In the present study, significant up-regulation of p21 and myogenin mRNA were observed at day 3 (positively correlated), indicating that a cell population (probably myoblast derived from SCs) was initiating the differentiation process. Unlike at day 3, exercise continuation for three additional days did not stimulate further increases but, in contrast, p21 and myogenin returned to the pre/exercise levels.

Despite the increased proliferation indices in an undefined cell population at day 7 , the fact that indirect indices of myoblast proliferation and differentiation were absent was a surprise and might; therefore, indicate an impaired adaptive response under repeated bouts of eccentric exercise. 


\section{CHAPTER VI}

\section{SUMMARY}

The purpose of the present study was to investigate the effects of repeated bouts of eccentric exercise for six consecutive days. This was done in an attempt to examined the effects and subsequently determine the appropriateness of exercise continuation with damaged muscles.

In order to resolve this issue we have examined direct (myofiber and sarcolemma damage) and indirect indices (CK and LDH activity, MAT, and DOMS) of skeletal muscle damage. We also reasoned that the molecular adaptations, under repeated bouts of eccentric exercise, would include down-regulation of inhibitory factors (Myostatin mRNA) and upregulation of positive regulatory factors (MRFs mRNA) associated with muscle growth and regeneration.

Fifteen males were recruited for this study, and were randomly assigned to exercise group (EX n=9) and control group (CON, n=9). The exercise group successfully completed 6sets of 15 reps of maximum voluntary eccentric contractions, for six repeated days, using a dynamometer (Multicont-II). The subjects of the control group remained relatively inactive and were asked to avoid any type of exercise. Three blood and muscle biopsy samples were obtained from each subject one week prior to exercise, at day 3 (48$\mathrm{h}$ post the first training session), and at day 7 ( $24 \mathrm{~h}$ after the last training session). Torque measurements were collected on a PC during all training sessions. Blood samples were collected in order to asses the, $\mathrm{CK}$ and LDH activities, indirect indices of muscle damage. Muscle biopsies were obtained from the vastus lateralis muscle in order to asses muscle damage and gene expression of the selected genes. Gene expression levels were determined using real-time RT-PCR. For the characterization of muscle damage all muscle samples processed by standard techniques to paraffin wax using standard haematoxylin- and eosin-staining. Additionally, immunohistochemical staining was

performed using antibodies against fibronectin and desmin antigens and all samples were observed via a Nikon Eclipse-E600 light microscope. 
The results of our study indicated no evidence of gross myofiber damage, no infiltration of inflammatory cells within the myofibers, no myofiber degeneration and/or necrosis. In addition no sarcolemma damage and no loss of desmin were observed as stained by anti-fibronectin and anti-desmin antibody respectively. Despite the lack of sarcolemma and myofiber damage, $\mathrm{CK}$ and LDH activities were significantly increased at all times measured. This indicates that leakage of myofibrillar proteins to the blood circulation, are poor and problematic indirect indices of sarcolemma and/or myofiber damage. Although no gross myofiber damage was observed, the gene expression results indicate an impaired adaptive response, since the mRNA expression of MRFs was attenuated. This is based to the fact a single bout of resistance exercise has been shown to induce the expression of MRFs and evidence also suggests that two-repeated bouts of resistance exercise stimulate greater responses. Even though, in the present study we have utilized a training protocol, repeated for six consecutive days, the mRNA expression of MRFs was minimal throughout the experimental period.

In the current study our aim, as noted, was to examine the effects and subsequently determine the appropriateness of exercise continuation with affected and/or "damaged muscles". Although we observed no gross myofiber and sarcolemma damage in 8 of 9 subjects we cannot ascertain the appropriateness of exercise continuation with affected muscles prior full recovery. This is due to the impaired expression patterns of MRFs that, with the exception of myogenin that showed a moderate non sustained increase, MyoD and MYf5 response was minimal. Under these conditions exercise continuation may be associated with impaired muscle growth and/or regeneration since MRFs are crucial in establishing the myogenic lineage and terminal differentiation of myoblasts; and also regulate the expression of several muscle specific genes like myosin, desmin and troponin.

The results of the present should be viewed with caution since variables like rest interval between exercise bouts; gender; age; activity level; etc. if taken into account may affect differently the applicability of the present findings. More over it should be noted that any conclusion made as a result of the findings of the present study, particularly concerning the myogenic response, is based on mRNA alterations. Whether protein alterations have indeed occurred remains to be elucidated. 
Therefore, issues like the aforementioned should be examined by future studies to provide more information regarding the continuation of exercise with affected muscles.

\subsection{Conclusions}

Based on the presented findings and within the limitation of this study, we conclude that:

- Repeated bouts of eccentric exercise, for six consecutive days, dramatically decreased Myostatin mRNA expression but impaired the expression patterns of MRFs such that, with the exception of myogenin that showed a moderate non sustained increase, MyoD and MYf5 response was minimal.

- Repeated bouts of eccentric exercise, for six consecutive days, do not cause gross sarcolemma damage in the mid-belly of Vastus Lateralis, in humans.

\subsection{Recommendations for future studies}

Based on the findings of the present study the following recommendations are offered for further research:

- An investigation should be performed to examine the effects of repeated bouts of eccentric exercise on myogenic responses by analyzing concomitantly mRNA and protein levels. Because mRNA and protein levels do not follow a direct 1:1 relationship, concomitant analysis will better clarify the effects of repeated bouts of eccentric exercise on myogenic responses.

- An investigation should be performed in order to examine the effects of longer rest intervals between the repeated bouts of eccentric exercise. These intervals should be greater than those used by the present study (24h). This will help determine whether rest intervals are determinant of myogenic responses. Subsequently, it may also clarify the reason for the attenuated MRFs mRNA expression observed by the present study.

- An investigation should be performed to examine the effects of repeated bouts of eccentric exercise on muscle damage by analyzing muscle tissue from various 
muscle portions. Such investigations may be carried out using open muscle biopsies by the help of which greater amount of tissue can be obtained and exclude hypercontraction of muscle fibers. This will help to exclude the possibility of damage at the different portions of the muscle.

- Further studies dealing with eccentric contraction induced muscle damage should examine concomitantly the content of myofibrillar proteins intramuscularly and in the blood. This would help determine whether the increased content of myofibrillar proteins in the blood is a consequence of intramuscular decreased content. Subsequently, the appropriateness of myofibrillar proteins in the blood as indirect indices of muscle damage can be evaluated.

- Further studies should examine skeletal muscle biopsies, following EE, when the activities of myofibrillar proteins (e.g. CK and LDH) will return (after their peak) close to the pre-exercise level. This would determine whether there is a delay between the peak enzyme leakage and the overt of muscle damage in structural level as observed by Jones et al. 1986, and maybe the reason for observing no sarcolemma and/or muscle fiber damage in the present study. 


\section{REFERENCES:}

Armand AS, Launay T, Gaspera BD, Charbonnier F, Gallien CL, and C. C. 2003. Effects of eccentric treadmill running on mouse soleus: degeneration/regeneration studied with Myf-5 and MyoD probes. Acta Physiol Scand. 179:75-84.

Armstrong RB, Warren GL, and Warren JA. 1991. Mechanisms of exercise-induced muscle fibre injury. Sports Med. 12:184-207.

Baker BA, Mercer RR, Geronilla KB, Kashon ML, Miller GR, and Cutlip RG. 2006. Stereological analysis of muscle morphology following exposure to repetitive stretch-shortening cycles in a rat model. Appl. Physiol. Nutr. Metab. 31:167-179.

Bickel CS, Slade JM, Haddad F, Adams GR, and Dudley GA. 2003. Acute molecular responses of skeletal muscle to resistance exercise in able-bodied and spinal cordinjured subjects. J Appl Physiol. 94:2255-2262.

Bickel CS, Slade JM, Mahoney ED, Haddad F, Dudley GA, and Adams GR. 2005. Time course of molecular responses of human skeletal muscle to acute bouts of resistance exercise. J Appl Physiol. 98:482-488.

Bogdanovich S, Perkins K J, Krag T O B, Whittemore L A, and Khurana T S. 2005. Myostatin propeptide-mediated amelioration of dystrophic pathophysiology. FASEB J. 6:543-549.

Brown SJ, Child RB, Day SH, and Donnelly AE. 1997. Indices of skeletal muscle damage and connective tissue breakdown following eccentric muscle contractions. Eur J Appl Physiol Occup Physiol. 75:369-74.

Bullough WS. 1965. Mitotic and functional homeostasis: a speculative review. Cancer Res. 25:1683-1727.

Chapman D, Newton M, Sacco P, and Nosaka K. 2006. Greater muscle damage induced by fast versus slow velocity eccentric exercise. Int J Sports Med. 27:591-8.

Charge SBP, and Rudnicki MA. 2004. Cellular and Molecular Regulation of Muscle Regeneration. Physiol Rev. 84:209-238.

Chen T C, and Nosaka K. 2006. Effects of number of eccentric muscle actions on first and second bouts of eccentric exercise of the elbow flexors. J Sci Med Sport. 1:57-66.

Chen TC. 2003. Effects of a second bout of maximal eccentric exercise on muscle damage and electromyographic activity. Eur J Appl Physiol. 89:115-121. 
Chen TC, and Hsieh SS. 2001. Effects of a 7-day eccentric training period on muscle damage and inflammation. Med Sci Sports Exerc:1732-1738.

Cheung K, Hume PA, and Maxwell L. Delayed Onset Muscle Soreness

Treatment Strategies and Performance Factors. Sports Med 33: 145-164, 2003.

Clarkson PM, and Hubal MJ. 2002. Exercise-Induced Muscle Damage in Humans. Am J Phys Med Rehabil. 81:S52-S69.

Cleary MA, Kimurat IF, Sitler MR, and Kendrick ZV. 2002. Temporal Pattern of the Repeated Bout Effect of Eccentric Exercise on Delayed-Onset Muscle Soreness. $J$ Athl Train. 37:32-36.

Crameri RM, Langberg H, Magnusson P, Jensen CH, Schroder HD, Olesen JL, Suetta C, Teisner B, and Kjaer M. 2004. Changes in Satellite Cells in Human Skeletal Muscle After a Single Bout of High Intensity Exercise. J Physiol. 558:333-340.

Crenshaw AG, Friden J, Hargens AR, Lang GH, and Thornell LE. 1993. Increased technetium uptake is not equivalent to muscle necrosis: scinigraphic, morphological and intramuscular pressure analyses of sore muscles after exercise. Acta Physiol Scand. 148.

Daniel R. Marsh, David S. Criswell, James A. Carson, and Frank W. Booth. 1997. Myogenic regulatory factors during regeneration of skeletal muscle in young, adult, and old rats J Appl Physiol. 83:1270-1275.

Dominique J E and Gerard C. 2006. Myostatin regulation of muscle development: Molecular basis, natural mutations, physiopathological aspects. Experimental Cell Research. 312:2401-2414.

Endl E and Gerdes J. 2000. The Ki-67 Protein: Fascinating Forms and an Unknown Function. Exp Cell Res. 257:231-237.

Fridén J, Sjöström M, and Ekblom B.1983. Myofibrillar damage following intense eccentric exercise in man. Int J Sports Med. 4:170-176.

Haddad F and Adams G. 2002. Selected contribution: Acute cellular and molecular responses to resistance exercise. J Appl Physiol. 93:394-403.

Hameed M, Orrell RW, Cobbold M, Goldspink G, and Harridge SDR. 2003. Expression of IGF-I splice variants in young and old human skeletal muscle after high resistance exercise. J Physiol. 574:247-254. 
Hortobagyi T, Houmard J, Fraser D, Dudek D, Lambert J, and Tracy J. 1998. Normal forces and myofibrillar disruption after eccentric exercise. J Appl Physiol. 84:492498.

Hough T. 1902. Ergographic studies in muscular soreness. Am J Physiol 7:76-92.

Jamurtas AZ, Theocharis V, Tofas T, Tsiokanos A, Yfani C, Paschalis V, Koutedakis Y, and Nosaka K. 2005. Comparison between leg and arm eccentric exercises of the same relative intensity on indices of muscle damage. Eur J Appl Physiol. 95:179185.

Jones DA, Newham DJ, Round JM, and Tolfree SEJ. 1986. Experimental human muscle damage: Morphological changes in relation to other indices of damage. J Physiol. 375:435-448.

Joulia D, Bernardi H, Garandel V, Rabenoelina F, Vernus B, and Cabello G. 2003. Mechanisms involved in the inhibition of myoblast proliferation and differentiation by myostatin. Exp Cell Res. 286:263-275.

Kim J, Cross JM, and Bamman MM. 2005. Impact of resistance loading on myostatin expression and cell cycle regulation in young and older men and women. Am J Physiol Endocrinol Metab. 288:1110-1119.

Kirk S, Oldham J, Kambadur R, Sharma M, Dobbie P, and Bass J. 2000. Myostatin regulation during skeletal muscle regeneration. J Cell Physiol. 184:356-63.

Komulainen J, Takala TES, Kuipers H, and Hesselink MKC. 1998. The disruption of myofibre structures in rat skeletal muscle after forced lengthening contractions. Eur J Physiol. 436:735-741.

Komulainen J, Takala TES, and Vihko V. 1995. Does Increased Serum Creatine Kinase Activity Reflect Exercise-Induced Muscle Damage in Rats? Int J Sports Med. 16:150-154.

Langley B, Thomas M, Bishop A, Sharma M, Gilmours S, and Kambadur R. 2002. Myostatin Inhibits Myoblast Differentiation by Down-regulating MyoD Expression. J Biol Chem. 277:49831-49840.

Lee J, Goldfarb AH, Rescino MH, Hegde S, Patrick S, and Apperson K. 2002. Eccentric exercise effect on blood oxidative-stress markers and delayed onset of muscle soreness. Med Sci Sports Exerc. 34:443-8.

Li H, and Capetanaki Y. 1993. Regulation of the mouse desmin gene: transactivation by MyoD, myogenin, MRF4, and Myf5. Nucleic Acid Res. 21:335-343. 
Lin H, Yutzey KE, and Konieczny SF. 1991. Muscle-specific expression of the troponin I gene requires interactions between helix-loop-helix muscle regulatory factors and ubiquitous transcription factors. Mol Cell Biol. 11:267-280.

Linnamo V, Strojnik V, and Komi PV. 2002. EMG power spectrum and features of the superimposed M-wave during voluntary eccentric and concentric actions at different activation levels. Eur J Appl Physiol. 86:534-40.

Lovering RM, and De Deyne PG. 2004. Contractile function, sarcolemma integrity, and the loss of dystrophin after skeletal muscle eccentric contaction-induced injury Am J Physiol Cell Physiol. 286:C230-C238.

Mahoney DJ, Garey K, Fu M H, Snow R, Cameron SD, Parise G, and Tarnopolsky MA. 2004. Real-time RT-PCR analysis of housekeeping genes in human skeletal muscle following acute exercise. Physiol Genomics. 18:226-231.

Mauro A. 1961. Satellite cell of skeletal muscle fibers. J Biophys Biochem Cytol. 9:493495.

McCroskery S, Thomas M, Maxwell L, Sharma M, and Kambadur R. 2003. Myostatin negatively regulates satellite cell activation and self-renewal. $J$ Cell Biol. 162:1135-1147.

McCroskery S, Thomas M, Platt L, Hennebry A, Nishimura T, McLeay L, Sharma M, and Kambadur R. 2005. Improved muscle healing through enhanced regeneration and reduced fibrosis in myostatin-null mice. J Cell Sci. 118:3531-3541.

McHugh MP. 2003. Recent advances in the understanding of the repeated bout effect: the positive effect against muscle damage from a single bout of eccentric exercise. Sand J Med Sci Sports. 13:88-97.

McHugh MP, Connolly DA, Eston RG, and Gleim GW. 2000. Electromyographic analysis of exercise resulting in symptoms of muscle damage. J Sports Sci. 18:163-72.

McHugh MP, and Pasiakos S. 2004. The role of exercising muscle length in the protective adaptation to a single bout of eccentric exercise. Eur Appl J Physiol. 93:286-293.

McPherron AC, Lawler AM, and Lee SJ. 1997. Regulation of skeletal muscle mass in mice by a new TGF-beta superfamily member. Nature. 387:83-90.

McPherron AC, and Lee SJ. 1997. Double muscling in cattle due to mutations in the myostatin gene. Proc Natl Acad Sci U S A. 94:12457-12461. 
Megeny LA, and Rudnicky MA. 1995. Determination versus differentiation and the MyoD family of transcription factors. Biochem Cell Biol. 73:723-732.

Mendler L, Zádor E, Ver Heyen M, Dux L, and Wuytack F. 2000. Myostatin levels in regenerating rat muscles and in myogenic cell cultures. J Muscle Res Cell Motil. 21:551-63.

Nosaka K, and Clarkson PM. 1992. Relationship between Post-Exercise Plasma CK Elevation and Muscle Mass Involved in the Exercise. Int J Sports Med. 13:471475.

Nosaka K, and Clarkson PM. 1995. Muscle damage following repeated bouts of high force eccentric exercise. Med Sci Sports Exerc. 27:1263-9.

Nosaka K, and Newton M. 2002. Repeated Eccentric Exercise Bouts Do Not Exacerbate Muscle Damage and Repair. J Strength Cond Res. 16:117-122.

Nosaka K, Sakamoto K, Newton M, and Sacco P. 2001. How long does the protective effect on eccentric exercise-induced muscle damage last? Med Sci Sports Exerc. $33: 1490-1495$.

Paddon-Jones D, Muthalib M, and Jenkins D. 2000. The effects of a repeated bout of eccentric exercise on indices of muscle damage and delayed onset muscle soreness. J Sci Med Sport. 3:35-43.

Peters D, Barash IA, Burdi M, Yuan PS, Mathew L, Friden J, and Lieber RL. 2003. Asynchronous functional, cellular and transcriptional changes after a bout of eccentric exercise in the rat. $J$ Physiol. 553:947-957.

Proske U, and Morgan DL. 2001. Muscle damage from eccentric exercise: mechanism, mechanical signs, adaptation and clinical applications. J Physiol. 537:333-345.

Psilander N, Damsgaard R, and Pilegard H. 2003. Resistance exercise alters MRF and IGF-I mRNA content in human skeletal muscle. J Appl Physiol. 95:1038-1044.

Rathbone CR, Wenke JC, Warren GL, and Armstrong RB. 2003. Importance of satellite cells in the strength recovery after eccentric contraction-induced muscle injury. Am J Physiol Regul Integr Comp Physiol. 285:R1490-R1495.

Raue U, Slivka D, Jemiolo B, Hollon C, and Trappe S. 2006. Myogenic gene expression at rest and after a bout of resistance exercise in young (18-30 yr) and old (80-89 yr) women. J Appl Physiol. 101:53-9.

Rosser B W C, and Bandman E. 2003. Heterogeneity of protein expression within muscle fibers. J Anim Sci 81:E94-E101. 
Rosser BWC, Dean MS, and Bandman E. 2002. Myonuclear domain size varies along the lengths of maturing skeletal muscle fibers. Inter J Dev Biol. 46:747-754.

Roth SM, Martel GF, Ferell RE, Metter EJ, Hurley BF, and Rogers MA. 2003. Myostatin Gene Expression Is Reduced in Humans with Heavy-Resistance Strength Training: A Brief communication. Exp Biol Med. 228:706-709.

Scholzen T, and Gerdes J. 2000. The Ki-67 Protein: From the Known and the Unknown. J Cell Biol. 182:311-322.

Shibata M, Matsumoto K, Aikawa K, Muramoto T, Fujimura S, and Kadowaki M. 2006. Gene expression of myostatin during development and regeneration of skeletal muscle in Japanese Black Cattle. J Anim Sci. 84:2983-2989.

Thomas M, Langley B, Berry C, Sharma M, Kirk S, Bass J, and Kambadur R. 2000. Myostatin, a negative regulator of muscle growth, functions by inhibiting myoblast proliferation. J Biol Chem. 275:40235-43.

Thornell LE, Holmbom B, Eriksson A, Reiz S, Marklund S, and Naslund U. 1992. Enzyme and immunohistochemical assessment of myocardial damage after ischemia and reperfusion in a closed-chest pig model $J$ Mol Cell Cardiol. 29:2107-2124.

Wagner KR, Liu X, Chang X, and Allen RE. 2005. Muscle regeneration in the prolonged absence of myostatin. Proc Natl Acad Sci U S A. 102:2519-24.

Wentworth BM, Donoghue M, Engert JC, Berglund EB, and Rosenthal N. 1991. Paired MyoD-binding sites regulate myosin light chain gene expression. Proc Natl Acad Sci. 88:1242-1246.

Willoughby DS. 2004. Effects of Heavy Resistance Training on Myostatin mRNA and Protein Expression. Med Sci Sports Exerc. 36:574-582.

Yang Y, Creer A, Jemiolo B, and Trappe S. 2005. Time course of myogenic and metabolic gene expression in response to acute exercise in human skeletal muscle. J Appl Physiol. 98:1745-1752.

Yu JG, Malm C, and Thornell LE. 2002. Eccentric contractions leading to DOMS do not cause loss of desmin nor fibre necrosis in human muscle. Histochem Cell Biol. 118:29-34. 


\section{OWN PUBLICATION LIST}

\section{Articles related to the $\mathrm{PhD}$ thesis:}

Costa A., Dalloul H., Hegyesi H., Apor P., Csende Z., Racz L., Vaczi M., Tihanyi J. 2007. Impact of repeated bout of eccentric exercise on myogenic gene expression. Eur J Appl Physiol. 101(4):427-436

Costa A., Orosz Z., Apor P., Csaba N., Siamilis S., Csende Z., Racz L., Tihanyi J. 2008. Impact of Repeated Bouts of Eccentric Exercise on Sarcolemma Disruption in Human Skeletal Muscle. Acta Physiol Hung. 96 (2):189-202

\section{Articles not related to the PhD thesis:}

Siamilis S., Jakus J., Nyakas C., Costa A., Mihalik B., Falus A., Radak Z.(2008). The effect of exercise and oxidant-antioxidant intervention on the levels of neurotrophins and free radicals in spinal cord of rats. Spinal Cord. [Epub ahead of print]

Apor P., Tihanyi J., Costa A. (2007).Improvement of muscle mass and force by certain hormones and endogen factors, contributing in muscle development. Orv Hetil. 148(10):451-6

Tihanyi J., Costa A., Váczi M., Sáfár S., Rácz L. (2008). Active torque enhancement during voluntary eccentric contraction. MSTT. 34:15-25

\section{Conference Proceedings (abstracts):}

Costa A., Hicham D., Zsolt C., Hegyesi H., Tihanyi J. (2006). Impact of chronic eccentric exercise on MRFs, myostatin and MYH3 mRNA expression in human skeletal muscle. Proceedings of $11^{\text {th }}$ annual Congress of the European college of Sport Science, 137-138.

Costa A., Hicham D., Zsolt C., Tihanyi J. (2005). Indirect markers of skeletal muscle damage by 6 -days eccentric exercise. Proceedings of the $5^{\text {th }}$ annual Congress of Sport Science.

Racz L., Vaczi M., Costa A., Safar S., Tihanyi J. (2006). Effect of stretching velocity on active and passive force enhancement. Proceedings of the $11^{\text {th }}$ annual Congress of the European college of Sport Science, pp 373.

Tihanyi J., Racz L., Trzaskoma L., Costa A. (2006). Influence of passive force enhancement on active force enhancement. Proceedings of the $11^{\text {th }}$ annual Congress of the European college of Sport Science, pp 459.

CUMULATIVE IMPACT FACTOR: 3.783 


\section{ACKNOWLEDGEMENTS}

First and foremost I offer my sincerest gratitude to my supervisor, Prof. Tihanyi Jozsef, who has supported me throughout my studies with his patience and knowledge whilst allowing me the room to work in my own way. He never accepted less than my best efforts and without him this thesis would not have been completed or written. One simply could not wish for a better or friendlier supervisor.

Besides, I would like to express my gratitude to Dr Zsolt Csende, Dr Hegyesi Hargita, and Dr Orosz Zsolt who advised, encouraged and challenged me throughout my academic program. Moreover, I thank my parents and my friend Savva Siamili for their support throughout these years. I thank you all, truly. 
APPENDIX A

Informed consent form 


\section{INFORMED CONSENT FORM}

\section{Impact of repeated bouts of eccentric exercise on skeletal muscle morphology and myogenic gene expression}

1. Mr. Costa Andreas, who is a PhD student at the Semmelweis University, Department of Biomechanics, invite me to participate in a study that will address the mechanical and morphological characteristics of human striated as a result of repeated bouts of eccentric exercise.

2. I have been informed that the aim of the study is to determine the mechanical and morphological characteristics of human striated as a result of repeated bouts of eccentric exercise.

3. The research will last six days and I agree to perform the following activities depending on which group I will be assigned to.

\section{Exercise group}

Complete six sets of 15 single leg maximum voluntary contractions (MVC), for six consecutive days using the non-dominant knee extensors. The angular velocity of each contraction will be $120 \%$ in a range of motion of 120 .

\section{Control group}

Avoid any kind of exercise or vigorous activity and follow the exact instructions of the research team.

Regardless of the group I will be assigned to I certify that:

- I will allow, a certified Doctor, to collect three muscle biopsy samples from my Vastus Lateralis muscle. The samples will be taken one week before the training period, immediately after the 3rd training session and by the end of the training period.

- I will allow, a certified nurse, to collect three blood samples $(100 \mathrm{ml})$. The samples will be taken one week before the training period, immediately after the 3rd training session and by the end of the training period.

4. I have been informed of all possible risks of my participation which may include the following:

- Unpleasant feeling at the place where the biopsy is taken

- Prolonged hemorrhage at the place where the biopsy is taken

- Transient damage and/or inflammation at the place where the biopsy is taken and/or the surrounding tissues.

- Prolonged pain 
5. I understand that there is no alternative method for the test to be performed.

6. The potential benefits is that the investigation will provide for my participation:

- Remuneration

- Close understanding of a scientific research

7. I understand that the results of the test might have to be published, but the persons name will not be available to the public. In order to have confidential treatment Mr. Costa Andreas will assign codes for all participants. Access to the personal data of each participant will be allowed only for Prof. Tihanyi Joseph, Mr. Costa Andreas, and Mr. Dalloul Hicham.

8. I understand that any damage to my self during the tests and/or the training period will be covered by my self.

9. I declare that I have been informed by the research team; concerning my remuneration and that I have accepted it.

10. I declare that I have been informed, by the research team, that any questions before, during and after my participation will be answered by Prof. Tihanyi Joseph, Mr. Costa Andrea or Mr. Dalloul Hicham.

11. I understand that if I feel that I am exposed to danger or have any question regarding my participation that is not successfully answered by the research team I have the right to refer it to the Chairman of the human subjects Research Review Committee.

12. I have read and understood all of the above information. I understood all possible risks and benefits and I understood that my participation can be interrupted at any time without any consequences. I have received a copy of this consent form.

Participant's Signature:

Date:

13. I declare that I have informed the participant concerning the investigation details, the possible risks and benefits, the investigation progress, and I declare that the research team will answer any future questions of the participant.

14. I gave a copy of this consent form to the participant

Researcher's Signature:

Date: 


\title{
Hozzájárulási nyilatkozat
}

\author{
Impact of repeated bouts of eccentric exercise on skeletal muscle \\ morphology and myogenic gene expression
}

1, Costa Andreas úr felkérésére, aki a Semmelweis Egyetem Doktori Iskolájának hallgatója, és PhD munkáját a Semmelweis Egyetem Testnevelési és Sporttudományi Kar Biomechanika Tanszékén végzi, részt veszek a fent említett tanszék tudományos kutatásában. A kutatás címe: A humán harántcsíkolt izom mechanikai, és morfológiai tulajdonságai nyújtás hatására.

2, Informáltak arról, hogy a vizsgálat célja a vastus lateralis izom mechanikai, és morfológiai tulajdonságainak elemzése, ismétlődő nyújtási behatás után.

3, A vizsgálat hat napos. Attól függően hogy véletlenszerü beosztással melyik vizsgálati csoportba kerülök, vállalom hogy a vizsgálat időbeosztását betartom, és végrehajtom.

Edzett csoport - A musculus quadriceps femoris aktív nyújtása 6 egymást követő napon keresztül részt veszek, amire naponta a következőképp kerül sor: Hat sorozat, minden sorozatban 15 darab aktív nyújtás konstans 120 \% szögsebességgel. Az izületi mozgástartomány 120 ?.

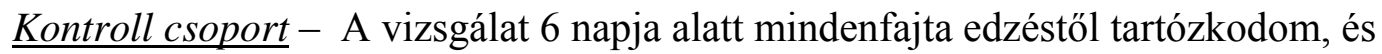
követem a kutatók utasításait.

Függetlenül attól hogy melyik csoportba kerülök, vállalom hogy:

- Mintát adok a musculus quadriceps femoris vastus lateralisból, melyet szakorvos kivitelez, biopsziás mintavételi technikával. A mintavételekre az edzésperiódus előtt, a 3. edzésnap után, és az edzésperiódus befejeztével kerül sor.

- $\quad 100 \mathrm{ml}$ vénás vért adok a könyökrégióból, melyet diplomás ápolók kiviteleznek. A vérvételekre az edzésperiódus elött, a 2. és a 3. edzésnap után, valamint az edzésperiódus után kerül sor.

4, Tudomásul veszem hogy a vizsgálatban való részvétel szövődményekkel, kellemetlenséggel járhat. Ezek a következők lehetnek:

-Véraláfutás, kellemetlen érzés a biopszia helyén

-Elhúzódó vérzés a biopszia helyén

-A biopsziás seb elfertőződése

-Az izom, és a környező szövetek átmeneti sérülése

-Húzó, feszítő érzés a biopszia közben

-Égető érzés az érzéstelenítés közben

-elhúzódó fájdalom

5, Tudomásul veszem, hogy a vizsgálatnak nincs lehetséges alternatív módja.

6, A lehetséges haszon, illetve elöny, amit a vizsgálatban való részvétel nyújt: 
-Információ a combfeszítỏ izom rostösszetételéről

-Egy tudományos kutatás közelebbi megismerése

-Részvételemért cserébe díjazást kapok

7, Tudomásul veszem, hogy a vizsgálat eredményei publikálásra kerülhetnek, de a vizsgálati személyek neve nem kerül nyilvánosságra. Adataim bizalmas kezelése érdekében Costa Andreas úr kódokat rendel a vizsgálati személyekhez a minták, eredmények további kezeléséhez. A bizalmas, személyes adatokhoz csak a vizsgálat vezetöjének Dr. Tihanyi József úrnak, Costa Andreas úrnak, és Dalloul Hicham úrnak van hozzáférése.

8, Tudomásul veszem, hogy a vizsgálat alatt keletkező bármely jellegü sérülés kezelésének költségterhét magam vállalom.

9, Kijelentem, hogy a kutatók tájékoztattak arról, hogy a vizsgálatban való részvételemért díjazásban részesülök.

10, Kijelentem, hogy a kutatók tájékoztattak arról, hogy a vizsgálatban való részvétel alatt, előtt, és után felmerülő kérdéseimre Costa Andreas úr, Dr. Tihanyi József úr, vagy Dalloul Hicham úr fog válaszolni.

11, Tudomásul veszem, hogy amennyiben sérülés ér a vizsgálat alatt, ha kérdések merülnek fel bennem a jogaimat illetően, vagy úgy érzem, hogy veszélynek vagyok kitéve, Az emberi kísérleteket vizsgáló bizottság elnökségéhez fordulhatok. (Chair of the Human Subjects Research Review Committee)

12, Elolvastam, és megértettem a fenti információkat. Tudomásul veszem a vizsgálat lehetséges szövődményeit, kellemetlenségeit, és hasznát. Tudomásul veszem, hogy a vizsgálat rizikókkal jár, amiket vállalok, és megértettem, hogy a vizsgálatban való részvételemet bármikor megszakíthatom. Ezen nyilatkozat aláirásával vállalom, hogy felmerülő sérelmeimre jogorvoslati igénnyel nem fogok élni. Ezen nyilatkozat másolatát megkaptam.

Vizsgálati személy aláírása:

Kelt:

13, Kijelentem, hogy a fenti vizsgálati személyt tájékoztattam a vizsgálatban való részvétel részleteiről, lehetséges szövődményeiről, annak díjazásáról, és hasznáról, a vizsgálat menetéröl, illetve kijelentem hogy a vizsgálati személyt széleskörüen informáltam a kutatás minden részletéről, kérdéseire válaszoltam, amit aláírásával igazolt.

14, A vizsgálati személynek nyilatkozat egyik példányát átadtam.

Kutató Aláírása:

Kelt: 


\section{APPENDIX B}

\section{Basic Anatomy and Physiology of Skeletal Muscle Tissue}

\&

Indices of skeletal muscle damage 


\section{Basic Anatomy and Physiology of Skeletal Muscle Tissue}

Skeletal muscle cells are responsible for all movements that are under voluntary control. Each cell is a syncytium, containing many nuclei within a common cytoplasm, and often referred to as muscle fiber. The multiple nuclei arise from the fact that each muscle fiber develops from the fusion of many cells (called myoblasts). Muscle cells contain most of the structures common to all cells. Each cell is enclosed by a cell membrane referred to as sarcolemma; they contain mitochondria for the oxidative metabolism of nutrients; and all the machinery necessary for protein synthesis. The smallest contractile unit of a muscle fiber is a sarcomere which composes of thin and thick myofillaments. The length of a sarcomere is $2 \mu \mathrm{m}$ length and is able to contract approximately $70 \%$ of its length. Sarcomeres are linked end to end to form a myofibril. Each muscle fiber can contain hundreds of myofibrils bathed in cytoplasm that in case of muscle referred to as sarcoplasm. Around myofibrils lies a network of tubules, the sarcoplasmatic reticulum, which is a specialized calcium store necessary for muscle contraction. Due to the precise arrangement of the sarcomeres within myofibrils various landmarks can be identified (Picture1B). These landmarks include: $\mathrm{Z}$ lines or $\mathrm{Z}$ discs, and $\mathrm{A}, \mathrm{I}$, and $\mathrm{H}$ bands. The $\mathrm{Z}$ lines are formed by interconnections of the thin myofillaments from adjacent sarcomeres and two adjacent $\mathrm{Z}$ lines define a sarcomere. The dark A bands of the sarcomere are formed by thick (myosin) and thin (actin) myofillaments. The $\mathrm{H}$ band is the lighter part if the A band that contains only myosin filaments. Adjacent to A band is the lighter I band that contains only actin filaments. During contraction, the actin filaments slides over the myosin filaments, resulting in a decrease in width of the I and $\mathrm{H}$ bands and the distance between the $\mathrm{Z}$ lines.

The units of a muscle tissue are organized by the use of a fibrous connective tissue network called fascia (Picture1A). The entire muscle is covered by a fascia called epimysium. Muscle fibers are arranged in muscle bundles called fascicles by a fascia named the perimysium while single muscle fibers are covered by the endomysium. At either end of the muscle belly, this matrix becomes the tendon that connects the muscle to bone.

Skeletal muscles have an abundant supply of blood vessels and nerves. This is directly related to the primary function of skeletal muscle, contraction. Before a skeletal 
muscle fiber can contract, it has to receive an impulse from a nerve cell. In this respect, skeletal muscle differs from smooth and cardiac muscle that can contract without being stimulated by the nervous system.

Nerve impulses (action potentials) traveling down the motor neurons of the sensorysomatic branch of the nervous system cause the skeletal muscle fibers at which they terminate to contract. The junction between the terminal of a motor neuron and a muscle fiber is called the neuromuscular junction. The terminals of motor axons contain thousands of vesicles filled with acetylcholine. When an action potential reaches the axon terminal, these vesicles discharge their acetylcholine which causes a rapid depolarization of muscle fiber under the motor end plate. Briefly, the interior of a resting muscle fiber has a resting potential of about $-90 \mathrm{mV}$. Stimulation of muscle fiber by the alpha motor increase the permeability of sarcolemma and due to ion's concentration gradient, sodium ions $\left(\mathrm{Na}^{+}\right)$diffuse inside the muscle fiber until the muscle fiber reverse its polarity to +30 $\mathrm{mV}$ positive inside with respect to outside. Near the peak of the reverse polarity, the decreased influx of $\mathrm{Na}^{+}$and the increased efflux of potassium ions $\left(\mathrm{K}^{+}\right)$cause a rapid repolarization of the muscle fiber. This rapid depolarization and the subsequent repolarization of the muscle fiber is the action potential.

No visible change occurs in the muscle fiber during (and immediately following) the action potential. This period, called the latent period, lasts from 3-10 msec. The process of contracting takes some $50 \mathrm{msec}$ while relaxation of the fiber takes 50-100 msec. When a muscle is stimulated with a single action it responds with a single "twitch". The period needed to restore the resting potential is called the refractory period and is brief (1-2 msec). Because the refractory period is so much shorter than the time needed for contraction and relaxation, the fiber can be maintained in the contracted state so long as it is stimulated frequently enough (e.g., 50 stimuli per second). Such sustained contraction is called "tetanus". As we normally use our muscles, the individual fibers go into tetanus for brief periods rather than simply undergoing single twitches. 
A

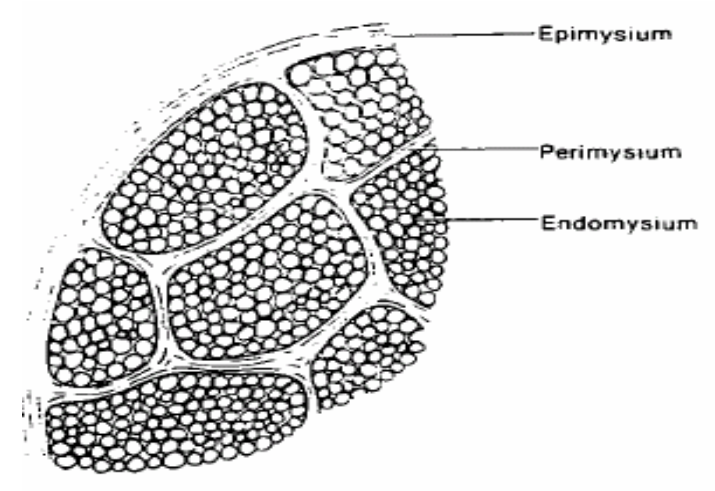

B

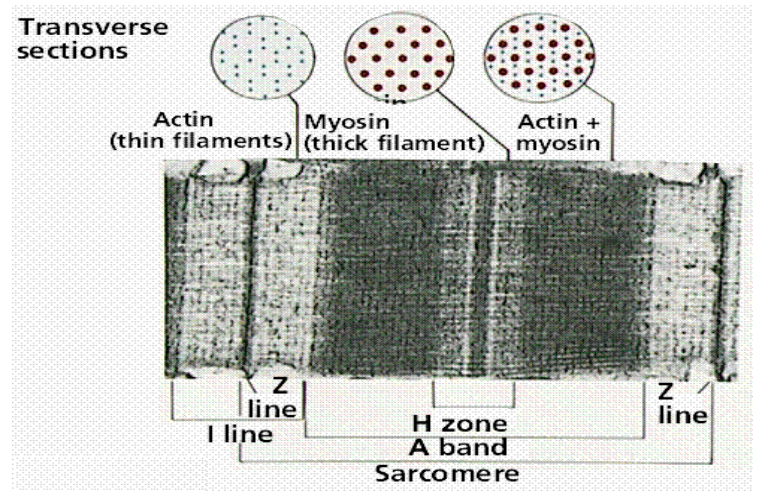

Picture 1. The endomysium, perimysium, and epimysium arrangement in skeletal muscle as seen in cross section (Picture1A). The ultrastructural structure of a single sarcomere (from $\mathrm{Z}$ line to $\mathrm{Z}$ line) and the arrangement of $\mathrm{A}, \mathrm{I}$ and $\mathrm{H}$ bands (Picture1B).

Pictures from: Muscles, Molecules and Movement, by Bendall JR, 1971, New York, American Elsevier Publishing. 


\section{Indices of skeletal muscle damage}

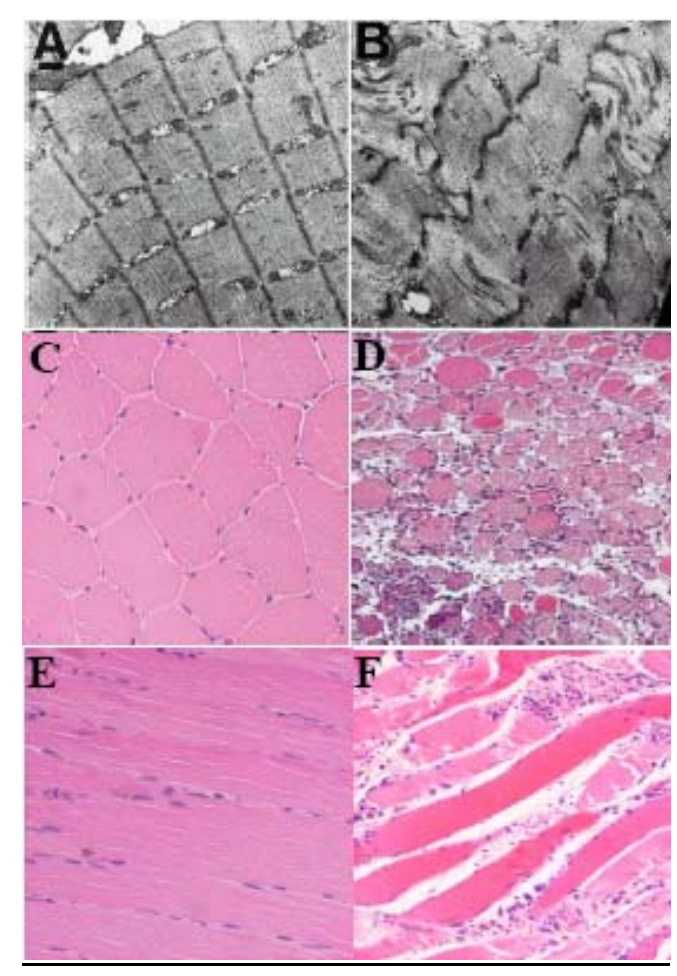

Picture 2. Longitudinal (A, B, E and F) and cross (C and D) sections of undamaged (right panel) and damaged (left panel) muscle. The ultrastructural appearance of undamaged (A) muscle shows well ordered sarcomeres while in damaged muscle (B) clear myofillament disorganization is evident. In structural level undamaged muscle fibers are characterized by tightly packed fibers ( $\mathrm{C}$ and $\mathrm{E}$ ), having a polygonal appearance $(\mathrm{C})$ and peripherally located myonucleus ( $\mathrm{C}$ and $\mathrm{E}$ ). As seen in cross (D) and longitudinal (F) sections of damaged muscle, most of the fibers appear in degenerative stage with rounded or enlarged appearance and infiltration of mononuclear cells.

Pictures (A and B) from: Hortobagyi T., Houmard J., Fraser D., Dudek R., Lambert J., and Tracy J. Normal forces and myofibrillar disruption after repeated eccentric exercise. J. Appl. Physiol. 84 (2): pp 496, 1998. Picture (D) form: Hawke TJ., and Garry DJ. Myogenic satellite cells: physiology to molecular biology. J. Appl. Physiol. 91: pp 545, 2001. 


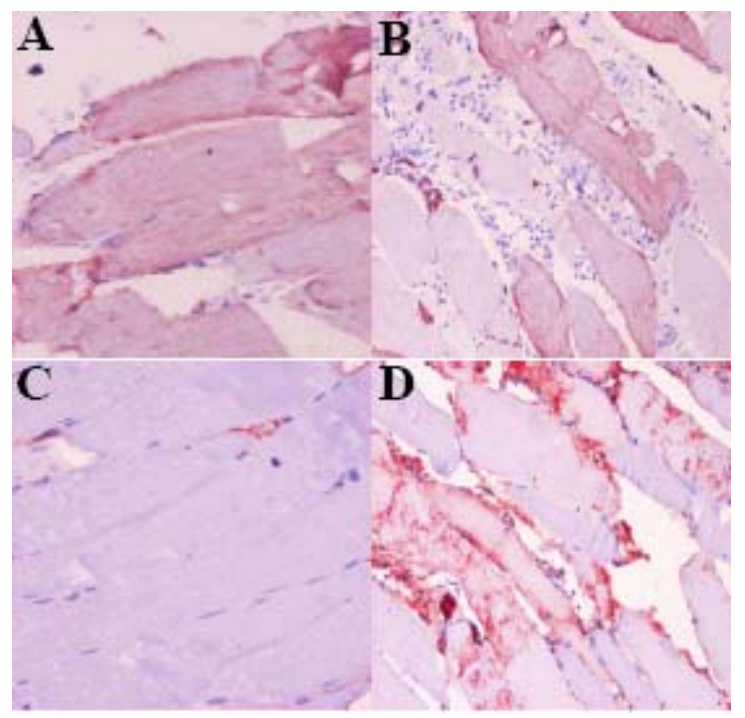

Picture 3. Desmin (A and B) and fibronectin (C and D) staining, in undamaged (right panel) and damaged (left panel) muscle. Loss of desmin staining (B) indicates damage to desmin intermediate filament. Intracellular localization of fibronectin is an indicator of sarcolemma damage because fibronectin is excluded in fibers with undamaged sarcolemma (D). 